\title{
Between Prospero and Caliban: Colonialism, Postcolonialism, and Inter-identity
}

\author{
Boaventura de Sousa Santos
}

\begin{abstract}
Concentrando-se na análise dos processos identitários no espaço-tempo da língua portuguesa, este trabalho pretende ser um contributo para o estudo do pós-colonialismo. Se a identidade moderna ocidental é, em grande medida, produto do colonialismo, a identidade no espaçotempo de língual portuguesa reflecte as especificidades do colonialismo português. Trata-se de um colonialismo subalterno, ele próprio "colonizado" em sua condição semi-periférica, que não é facilmente entendido à luz das teorias que hoje dominam o pensamento pós-colonial nos países centrais, um pensamento baseado no colonialismo hegemónico. $O$ autor propõe 0 conceito de inter-identidade para dar conta de uma constelação identitária complexa, em que se combinam traços de colonizador com traços de colonizado. A falta e a saudade de hegemonia (ou imaginação do centro) propiciou a formacção de colonialismos internos que perduram até hoje. À luz disto, o autor conclui que o pós-colonialismo no espaço-tempo de língua portuguesa-um pós-colonialismo situado-deve manifestar-se, em tempo de globalização neoliberal, como anti-colonialismo e globalização contra-hegemónica.
\end{abstract}

\section{INTRODUCTION}

The aim of this essay is to further ongoing research on identity processes in the timespace of the Portuguese language. A vast, multi-secular contact zone is implied involving the Portuguese people and other peoples of America, Asia, and Africa. The working hypotheses were formulated in previous work (Santos, 1994: 49-67 e 119-137). Let me recall them here briefly. First, Portugal is and has been since the seventeenth century a semiperipheral country in the modern capitalist world system. This condition best characterizes the modern long duration of Portuguese society. Although this condition has evolved across centuries, it has kept its basic features: an intermediate economic development and a position of intermediation between the center and the periphery of the world economy; a state which, being both product and producer of that intermediate position, never assumed fully the characteristics of the modern state of the core countries, particularly those consolidated in the liberal state since the mid-nineteenth century; cultural processes and systems of representation that do not adjust well to the typical binarisms of western modernity-such as culture/nature, civilized/uncivilized, modern/traditional-and may therefore be considered originally hybrid, even if ultimately merely different (a difference, incidentally, that cannot be understood in its own terms).

My second working hypothesis is that this complex semiperipheral condition reproduced itself until quite recently on the basis of the colonial system and, for the past fifteen years, has continued to reproduce itself in the way in which Portugal has become part of the European Union. From the latter hypothesis derive three sub-hypotheses. First, Portuguese colonialism, featuring a semiperipheral country, was also semiperipheral itself. It was, in other words, a subaltern colonialism. Portuguese colonialism was the result both of a deficit of colonization-Portugal's incapacity to colonize efficiently-and an excess of 
colonization - the fact that the Portuguese colonies were submitted to a double colonization: Portugal's colonization and, indirectly, the colonization of the core countries (particularly England) of which Portugal was dependent (often in a near colonial way).

The second sub-hypothesis is that, because of its characteristics and historical duration, the colonial relation reenacted by Portugal affected in a particular way the configurations of social, political, and cultural power, not only in the colonies but inside Portuguese society itself. While modern capitalist power has always been colonial, in Portugal and its colonies it was always more colonial than capitalist. This condition, far from coming to an end with the end of colonialism, is still being reproduced. In other words, perhaps more so than as regards any other European colonialism, the end of Portuguese colonialism did not determine the end of the colonialism of power, either in the colonies or in the former colonial power. The third sub-hypothesis is that, in spite of its very short-time duration when compared with the colonial cycle, Portugal's integration in the European Union seems destined to have as dramatic an impact on Portuguese society as colonialism. The meaning and content of this impact is still an open question. As of now, it seems to lean towards reproducing, in new terms, the semiperipheral condition.

The third general hypothesis that has come to guide my research concerns these two last questions, and particularly the analytical value of the theory of the world system under the current conditions of globalization. I have dealt with this topic elsewhere (Santos, 2001). Here, I will limit myself to enunciating the working hypothesis I then developed.

I believe that we find ourselves in an unstable phase characterized by the overlapping of two forms of hierarchization: one, more rigid, constitutes the world system from its beginning as center, semi-periphery, and periphery; another, more flexible, distinguishes between what in the world system is produced or defined as local and what is produced or defined as global. ${ }^{1}$ Whereas the former hierarchy continues to operate in relations among national societies or economies, the second one occurs among domains of activities, practices, knowledges, and narratives, be they economic, political or cultural. The overlapping of these two forms of hierarchy and the reciprocal interferences they generate explain the paradoxical situation we are in: inequalities inside the world system (and inside each society that comprises it) get worse, while the factors that cause them and the actions that might eventually reduce them are increasingly difficult to identify.

Finally, the fourth general working hypothesis is that the Portuguese culture is a borderland culture. It has no content. It does have form, however, and that form is the borderland zone. National cultures are a creation of the nineteenth century, the historical product of a tension between universalism and particularism as managed by the state. The state's role was twofold: on the one had, it established the difference of the national culture as opposed to the outside; on the other, it promoted cultural homogeneity inside the national territory. My working hypothesis is that in Portugal the state never played any of these roles satisfactorily; as a consequence, the Portuguese culture always had a lot of trouble distinguishing itself from other national cultures, or if you wish it always had great capacity not to distinguish itself from other national cultures; it has, moreover, kept to this day a considerable internal heterogeneity. (Santos, 1994: 132-133). 


\section{Portuguese Colonialism AND Postcolonialism}

\subsection{The specificity of Portuguese colonialism}

To formulate the characterization of Portuguese colonialism as "specificity" implies the relations of hierarchy among the different European colonialisms. Specificity states a deviation in relation to a general norm. In this case, the norm is British colonialism, in relation to which the contours of Portuguese colonialism get defined as a subaltern colonialism. The subalternity of Portuguese colonialism is twofold: it occurs both at the level of colonial practices and at the level of discourses. Concerning practices, subalternity consists in the fact that Portugal, as a semiperipheral country, was itself for a long period a country dependent of England, at times an "informal colony" of England. As with Spanish colonialism, the convergence of Portuguese colonialism with capitalism was far less direct than in British colonialism. In many cases, this convergence occurred by delegation, that is to say, by the impact of England's pressure on Portugal through mechanisms such as unequal credit conditions and international treaties. Thus, while the British Empire was based on a dynamic balance between colonialism and capitalism, the Portuguese Empire was based on an equally dynamic imbalance between an excess and a deficit of colonialism.

As regards colonial discourses, the subalternity of Portuguese colonialism resides in the fact that, since the seventeenth century, the history of colonialism has been written in English, not in Portuguese. This means that the Portuguese colonizer has a problem of selfrepresentation rather similar to that of the British colonized. As we know, this problem, as far as the colonized are concerned, consists in the impossibility of the colonized, or the formerly colonized Third World, to represent themselves in terms such that do not confirm the subaltern position ascribed to them by the colonial representation. The near dilemmatic nature of this problem is that to upset this position might surreptitiously confirm subalternity in the very process of upsetting it.

As regards the Portuguese colonizer, this problem translates itself into the need to define Portuguese colonialism in terms of its specificity vis-à-vis hegemonic colonialism, which means the impossibility or difficulty of defining it in terms such that do not reflect subalternity, that is to say, in terms of what it was and not in terms of what it was not. A particularly complex research topic consists in assessing to what extent this problem of the Portuguese colonizer reverberates in the Portuguese colonized. Could it be that the Portuguese colonized have a double problem of self-representation: vis-à-vis the colonizer that colonized them, and vis-à-vis the colonizer that, not having colonized them, has nonetheless written the history of their colonial subjugation? Or, on the contrary, could it be that the problem of self-representation of the Portuguese colonizer creates a chaotic disjunction between the subject and the object of colonial representation, which in turn creates a field apparently empty of representations (but in fact full of sub-codified representations) that gives the colonized enough leeway to attempt their self-representation beyond or outside the representations of their subalternity? The question here is to determine whether the colonized by a subaltern colonialism are under-colonized or over-colonized.

The specificity of Portuguese colonialism resides, therefore, mainly in reasons of political economy - the country's semiperipheral condition ${ }^{2}$ - which does not mean that it manifests itself merely at the economic level. Quite the opposite, it manifests itself also at the social, political, juridical, and cultural levels; at the level of the daily practices of conviviality and survival, oppression and resistance, proximity and distance; at the level of discourses and narratives, common sense and other knowledges, emotions and affections, feelings and ideologies. Each one of these levels created its own materiality, its own institutionality and logic of development, which in turn acted back upon the semiperipheral 
condition, endowing it with a sociological density it would never have while referred only to a position in the world system. Hereby, semi-periphery stopped being the link in a hierarchy to become a way of being in Europe and overseas. The task of grasping this sociological and psychological reality and the scales, into which it crystallized itself, is still ahead. The difficulty lies in studying it so as to grasp what it was and not what it was not. But there is one more reason to add to the ones I mentioned above: the fact that the Portuguese colonial cycle was, amongst all European colonialisms, the longest, having preceded by three centuries the nineteenth-century capitalist colonialism of core countries. The latter, once consolidated, defined the rules of colonial practice-dramatically stated in the Berlin Conference (1884) and the Ultimatum (1890)-as well as the rules of colonial discourseracist science, progress, the "white man's burden," and so on. Portuguese colonialism adopted these rules in ways and degrees that are still largely to be assessed.

In the case of Portuguese colonialism (and likewise Spanish colonialism), a previous multi-secular reality was to be reckoned with, which, having been retroactively subjected to the new criteria of analysis and evaluation, was reduced to a deviant particularism (predatory, mercantilist, informal ${ }^{3}$ colonialism). Charles Boxer's historiography symbolizes this process better than any other. The enormous asymmetry between British and Portuguese colonialism resided in the fact that the former did not have to break with a past that did not coincide with its present. British colonialism was ever, from its very beginning, the norm, because its protagonist was the country that imposed the normativity of the world system. In the case of Portuguese colonialism, once the possibility of a retroactive colonialism as discourse of rupture and desynchrony was created, it could be manipulated according to political conjunctures and demands. It offered itself both to disquieting readings-e.g. the underdevelopment of the colonizer resulted in the underdevelopment of the colonized, a double condition that could only be overcome by a developed colonialist policy; as well as comforting readings-e.g. Luso-tropicalism, "Portugal from Minho to Timor," friendly colonialism. Almost all readings, however, had both disquieting and comforting aspects. The negativity of Portuguese colonialism was always the subtext of its positivity, and vice-versa.

Regardless of the originality of Portugal's participation in the project of European expansion, it could not sustain a discourse of originality about itself from the moment that industrial capitalism created a closer and more direct link with colonialism. From then on, originality, in its double sense of temporal priority and autonomous construction, gave way to derivation, particularism, and specificity. Thus, the dense and long temporality of Portuguese colonialism resulted in a strange suspension of time, an anachrony that indeed would turn out to be double: because it had existed before and continued to exist after hegemonic colonialism. Retroactivity, suspension, and anachronism ended up turning themselves into a temporality peculiar to a long duration subjected to strange criteria of temporality.

These games of temporality impregnated the sociabilities and identities of the colonizer and the colonized alike, short of and beyond the colonial politico-juridical ties. ${ }^{4}$ Short of the colonial politico-juridical ties, because for centuries in many regions of the empire the relations between the Portuguese and the local populations could not, in practical terms, claim any juridico-political link external to themselves or to the encounters that originated them or resulted from them; beyond the colonial politico-juridical ties, because the coloniality of relations did not end with the end of the colonialism of relations. This issue stirs another, larger one on the nature of the binomial colonialism/postcolonialism in the space of official Portuguese language. 


\subsection{Postcolonialism}

Postcolonialism must be understood in two main senses. The first one concerns a historical period, the period that succeeds the independence of the colonies. The second one is a set of (mainly performative) practices and discourses that deconstruct the colonial narrative as written by the colonizer, and try to replace it by narratives written from the point of view of the colonized. In the first sense, postcolonialism translates itself into a set of economic, sociological, and political analyses of the construction of new states. In the second sense, postcolonialism is part of cultural, linguistic, and literary studies, and privileges textual exegesis and the performative practices to analyze the systems of representation and the identity processes. It implies a critique, whether explicit or implicit, of the silences of postcolonial analyses in the first sense. Since I focus here on systems of representation and identity processes, I resort to postcolonialism in the second sense, although the analyses proper to postcolonialism in the first sense are constantly invoked as well.

The working hypothesis in this regard is that the difference of Portuguese colonialism cannot fail to induce the difference of postcolonialism in the space of official Portuguese language. As a contemporaneous intellectual current, postcolonialism is basically an AngloSaxon phenomenon and its founding reality is British colonialism. It aims to create intellectual space for the postcolonial critic, but the way it goes about it changes from author to author. Very distinct positions are thus identified in the field of analysis that claim to be postcolonial. I shall identify merely what they may have in common, this being all that matters for the thesis I here present.

Postcolonialism is a product of the "cultural turn" of the social sciences in the 1980s, having as forerunners Frantz Fanon $(1961 ; 1965)$ and Albert Memmi (1965). Drawing on the pioneer work of Edward Said on Orientalism (1978) and of Stuart Hall $(1989 ; 1996)$ on diasporic cultures, it consolidated itself mainly through the work of Partha Chatterjee (1986), Paul Gilroy (1993), Homi Bhabha (1994), Gayatri Spivak (1996) and the debates they stirred. It is basically a current animated by diasporic intellectuals, with roots in the countries colonized by the British Empire and working in the West. The decisive contribution of work undergone in these countries in the period after independence, as for example the "Subaltern Studies" conducted by Ranajit Guha (Santos, 1995: 506-518; 2000: 340-354), are not always duly credited by postcolonial critics.

This is not the place to deal at length with the major themes and concerns of mainstream postcolonial debates. However, a succinct overview of the field and what in it needs to be reconsidered in light of Portuguese colonialism and postcolonialism is in order.

Hybridity in identity regimes. Whereas colonial discourse was based on the polarity between the colonizer (Prospero) and the colonized (Caliban), postcolonialism underscores the ambivalence and hybridity between the two, since they are not independent of each other nor is each one thinkable without the other. ${ }^{5}$ Fanon's and Memmi's influence is decisive in this regard. According to Memmi, as according to Fanon, the link between colonizer and colonized is dialectically destructive and creative. It destroys and recreates the two partners of colonization as colonizer and colonized. The chain that links colonizer and colonized is racism, a chain, however, that is a form of aggression for the colonizer and a form of defense for the colonized (Memmi, 1965: 131). The construction of this difference required the creation of the ambivalent stereotype of the colonized as savage. The stereotype's most notorious ambivalence is the fact that it is also constituted by the opposite of its negative elements: the negro is simultaneously the savage and the most dignified and obedient servant; the incarnation of uncontrolled sexuality but also innocent as a child; mystic, 
primitive and simple minded, and, at the same time, ingenious, lier, and manipulator of social forces (Bhabha, 1994: 82).

Translation, by making cultural communication possible, undermines the whole idea of essentialism of an original and pure culture. Hence the centrality of the concepts of hybridity and mimicry. The ambivalence of mimicry is that it affirms difference in the very process of identifying the other. In the colonial context, race is the symbol of this difference, and in fact the cause of the failure of mimicry, since it does not allow for more than an incomplete presence. As Bhabha says, having India in mind, "to be Anglicized is emphatically not to be English" (Bhabha, 1994: 87). In the Portuguese context, it could also be said that to be assimilated is emphatically not to be Portuguese. By subverting essentialism, hybridity can alter the power relations between dominant and dominated meanings. Hybridity opens space by discrediting hegemonic representations, thereby displacing antagonism in such a way that it stops sustaining the pure polarizations that made it up.

Cultural difference and multiculturalism. By breaking with the clear distinction between the identity of the colonizer and the identity of the colonized, postcolonial identity must be constructed in the margins of representation, and by a movement that goes from the margins to the center. This is the privileged space of culture and the postcolonial critic, a liminal, in-between or borderland space. Cultural enunciation creates its own temporality. This specific temporality is what renders possible the emergence of alternative modernities to western modernity, precisely by means of "postcolonial translation." The anti-colonial liberation struggle itself is hybrid and based on translation. It does not sustain itself either in precolonial ancestrality or in pure and simple mimicry of western liberal ideals.

Nationalism and postcolonialism. The problem of nationalism assumes various dimensions in postcolonial discourse. The most important one concerns anti-colonial resistance. Postcolonial resistance resides mainly in the "decolonization of the image" mentioned by Ngäugäi wa Thiong'o (1986) and Achille Mbembe (2000). Partha Chatterjee clearly shows the contradictory and ambivalent nature of nationalism in the eastern countries that were subjected to British colonialism. What happens is that these countries are forced to adopt a "national form" that is hostile to their own cultures in order to fight against the western nationalism of the colonial powers (Chatterjee, 1986). Inasmuch as the affirmation of national identity becomes a weapon to fight against colonial exploitation, the national question in the non-European world is historically embedded in the colonial question (Chatterjee, 1986: 18). ${ }^{6}$ However, nationalist discourse (at least in India) frequently accepts the intellectual premises of modernity that ground colonial domination, while defying colonial domination itself. Among these premises is capitalism itself, whose universal impetus creates a permanent tension with nationalism, now under the form of an independent nation-state. The state mediates between nation and capitalism, but such mediation is a project destined to fail.

By contesting the idea of the homogeneity of cultures, postcolonial studies contest, whether implicitly or explicitly, the idea of nation or nationalism, since one and the other presuppose a certain cultural homogeneity upon which a national, anti-colonial identity may be grounded. The challenge consists, to my mind, in finding a balanced dosage of homogeneity and fragmentation, for there is no identity without difference, and difference presupposes a certain homogeneity to identify what is different in differences. Such was the challenge faced by intellectuals like Leopold Senghor $(1964 ; 1977)$, Aimé Césaire (1983; 1989), Frantz Fanon (1961), Kwame Nkrumah (1961; 1965), Julius Nyerere (1966), Eduardo Mondlane (1969), and Amílcar Cabral (1964), who were determined to build a national culture understood as the right of the colonized to self-signification. ${ }^{7}$ The construction of 
"national consciousness" (Fanon) must avoid the temptation of racism by giving voice to the popular classes, as suggested by the agenda of the Subaltern Studies Group. ${ }^{8}$ This is also the only way for nationalism to avoid the temptation of sexual discrimination (Nira Yuval-Davis, 1989: 116-117).

Postcolonialism and diaspora. The transnationality of diasporic communities is the central topic of the analysis of the Atlantic transit of blacks since slavery, "the middle passage" and its impact, both in representations of black communities and in the idea the West's ethnic and racial homogeneity (Gilroy, 1993). John McLeod refers to diasporas as "composite communities", dynamic spaces of construction and reconstruction of identities that challenge both the pattern of national identity and the notion of roots (McLeod, 2000: 211). Diaspora identities characterize what Stuart Hall designates as "new ethnicities" (1989; 1996). He means diasporic groups that contest the rigidity of the representations imposed on them in the name of their different social experiences and subjective positions (e.g. "black"), and look for alternative forms of organization to those sponsored by the dominant society for the sake of their own legitimation, rather than to solve the real problems of immigrants. ${ }^{9}$

Postcolonialism and postmodernism. In previous work, I have explored the relation between what I call oppositional postmodernism and postcolonialism (Santos, 1999). Postcolonialism-because of its emphasis on textuality or discursivity, hybridity, fragmentation, and performativity - has significant affinities with a certain kind of postmodernism. Indeed, the same authors inspire both: Nietzsche, Bakthine, Lacan, Barthes, Derrida. My critique of mainstream postmodernism, the version I designate as celebratory postmodernism, resides in the fact that it draws from the diagnosis of the crisis of the paradigm of modernity (which I share) the conclusion (which I do not share) that the modern aspirations of social change (liberty, equality, solidarity) must stop being a central problem of the social sciences. This conclusion carries along a series of theoretical and epistemological orientations, such as: utter indifference to issues of power, structural inequalities, and social exclusion in contemporary capitalist societies; reducing social reality to its discursivity, neglecting non-discursive practices; silencing the discursivity of the popular classes and oppressed social groups; obsessive insistence on textual deconstruction with the result that it becomes impossible to formulate resistance, since resistance itself is also trapped in the deconstruction of the power it constitutes as resistance to power.

\subsection{Beyond postcolonialism}

I resorted to postcolonialism to criticize celebratory postmodernism and offer an alternative: oppositional postmodernism. Resorting to postcolonialism was justified in that it places at the center of the analytical field a power relation that is particularly asymmetricalthe colonial relation. The analysis proper to postcolonialism, I suggested, might be relevant for the analysis of other kinds of asymmetrical social relations outside the modernist analytical canon. The proposed articulation with postcolonialism aimed then to ground utopian emancipatory practices and subjectivities outside the modernist canon. ${ }^{10}$ Resorting to a device dear to postmodernism and postcolonialism alike, I grounded the emancipatory utopias on three metaphors: the frontier, the baroque, and the South (Santos, 1995: 475-519; 2000: 305-354).

I used the concept of frontier, in the sense of extremity rather than contact zone or borderland, to signify the displacement of the discourse and practices from the center to the margins. I advanced a phenomenology of frontier marginality based on the selective and instrumental use of traditions; ${ }^{11}$ on the invention of new forms of sociability; on weak 
hierarchies; on the plurality of juridical powers and orders; on the fluidity of social relations; on the promiscuity between strangers and intimates, between inheritance and invention. ${ }^{12}$ "To live in the frontier," I concluded, "is to live in the margins without living a marginal life" (Santos, 1995: 496; 2000: 327).

The concept of the baroque allowed me to ground the concept of mestizaje, close to hybridity, and understood as "the creation of new forms of constellations of meaning, which are truly unrecognizable or blasphemous in light of their constitutive fragments" (Santos, 1995: 503; 2000: 335). The baroque metaphor also permitted a discussion of the construction of utopian subjectivity on the basis of baroque "extremosidad" (Maravall, 1990: 421), mainly the extremism of the baroque feast informed by disproportion, laughter, and subversion. Finally, I used the South metaphor to signify the systemic human sufferance caused by global capitalism. I meant, on the one hand, the size and multifaceted character of oppression in contemporary societies; on the other, the capacity for creation, innovation, and resistance of the oppressed peoples once they were liberated from their condition of victims. Unsuspected latent possibilities of emancipation reside in this capacity. I therefore proposed an epistemology of the South based on three orientations: to learn that the South exists; to learn how to go to the South; to learn from and with the South (Santos, 1995: 508; 2000: 342).

I conceive of the colonial relation as one of the unequal power relations on which modern capitalism is grounded, but not the only one. It cannot be fully understood without articulating it with other power relations, such as class exploitation, sexism, and racism (only partially taken into account by postcolonialism). The analysis of culture or discourse cannot do without the analysis of political economy. ${ }^{13}$ In the second half of the twentieth century the silences of postcolonialism became more strident. Authors like Anne McClintock (1995), Stuart Hall (1996), Patrick Chabal (1997), and John McLeod (2000) have addressed this issue eloquently. Aijaz Ahmad has pointed out that the striking absence of class problems in postcolonial criticism derives from the fact that postcolonial studies are the product of an academic and intellectual class that ignores the actual social problems or has no interest in them (Ahmad, 1995). Overlooking neocolonialism is one of the most disempowering limitations of postcolonialism. While eager to criticize homogeneity and applaud fragmentation and difference, postcolonialism ended up homogenizing the colonial relation because of its total lack of historical and comparative perspective. Even within the British Empire, there were wide differences among the Irish, Indian, Australian, Kenyan, South African, and other experiences. Not to mention other colonialisms, namely the Portuguese and Spanish colonialism.

\subsection{Portuguese colonialism and the silences of postcolonialism}

The difference of Portuguese colonialism must reflect itself in the difference of postcolonialism in the space of official Portuguese language, namely vis-à-vis Anglo-Saxon postcolonialism. For the sake of convenience, I use the expression Portuguese postcolonialism to designate postcolonialism in the time-space of official Portuguese language.

The first difference is that the ambiguity and hybridity between colonizer and colonized, far from being a postcolonial claim, was the experience of Portuguese colonialism for long periods of time. The practice of ambivalence, interdependence, and hybridity was a necessity of the Portuguese colonial relation. For this reason, what is important in the context of Portuguese postcolonialism is to distinguish among various types of ambivalence and hybridity, namely between those that reinforce the power inequalities of the colonial relation and those that minimize or even subvert them. 
Anglo-Saxon postcolonialism has its origin in a colonial relation based on the extreme polarization between colonizer and colonized-between Prospero and Caliban-a polarization that is both a practice of representation and the representation of a practice. The radical critique of Anglo-Saxon postcolonialism rightly addresses this polarization. But where are we to anchor a radical critique when such polarization has been largely weakened or strongly nuanced, namely as regards the cultural domain, and concerning particularly the daily experience of cultural practices mentioned by Bhabha? Portuguese postcolonialism must rather focus on the critique of ambivalence than on claiming it. The critique itself lies in distinguishing between the forms of ambivalence and hybridity that do indeed give a voice to the subaltern (emancipatory hybridity) and those that use the subaltern's voice to silence them (reactionary hybridity).

The second difference of Portuguese postcolonialism has to do with race and the color of the skin. For Anglo-Saxon postcolonial critics, the color of the skin is an inescapable limit to mimicry and assimilation practices. Depending on the cases, skin color either negates beyond enunciation what enunciation affirms, or, on the contrary, affirms what it negates. In the case of Portuguese postcolonialism, the ambivalence, or hybridity, of the very color of the skin must be taken into account: the mulatto man and woman. The in-between space, the intellectual zone that the postcolonial critics claim for themselves, incarnates in the mulatto man or woman as a body and corporeal zone. The desire of the other, upon which Bhabha grounds the ambivalence of the representation of the colonizer, is not in this case a psychoanalytic phenomenon, nor is it doubled in language (1994: 50). It is physical, creative, and engenders creatures. Far from being a failed mimetic gesture, the mulatto man and woman are the negation of mimicry. They affirm a limit a posteriori, that is to say, they are the affirmation of a limit that only affirms itself after having been overcome. They are the affirmation of the white and black man and woman at the very point of reciprocal elision. Miscegenation is not the consequence of the absence of racism, as argued by Lusocolonialist or Luso-tropicalist reasoning, but it certainly is the cause of a different kind of racism. The existence of ambivalence or hybridity is, therefore, trivial, as far as Portuguese postcolonialism is concerned. What is important is to understand the sexist rules of sexuality that usually allow the white man to sleep with the black woman, but not the white woman with the black man. In other words, Portuguese postcolonialism calls for a strong articulation with the question of sexual discrimination and feminism.

The third difference of Portuguese postcolonialism lies in a dimension of ambivalence and hybridity unsuspected in Anglo-Saxon postcolonialism. In Portuguese postcolonialism, the ambivalence of representation does not derive solely from the lack of a clear distinction between the identity of the colonizer and the identity of the colonized. It derives as well from the fact that the distinction is inscribed in the colonizer's own identity. The identity of the Portuguese colonizer does not simply include the identity of the colonized other. It includes as well the identity of the colonizer as in turn himself colonized. The Portuguese Prospero is not just a Calibanized Prospero; he is a very Caliban from the viewpoint of the European super-Prosperos. The identity of the Portuguese colonizer is thus doubly double. It is constituted by the conjunction of two others: the colonized other, and the colonizer as himself a colonized other. Because of this profound duplicity, the Portuguese were often emigrants, rather than settlers, in "their" own colonies. Indeed, in the genealogy of the mirrors upon which the Portuguese see themselves, it remains to be decided whether their identity as colonized does not precede their identity as colonizer.

The conclusion may therefore be drawn that the disjunction of difference (Bhabha, 1994) is far more complex in the case of Portuguese postcolonialism. Such complexity may, paradoxically, rebound as conjunction or unsuspected complicity between the colonizer and the colonized. The "other" colonized by the colonizer is not totally other vis-à-vis the 
colonizer's colonized "other." As opposed to Anglo-Saxon postcolonialism, there is not one single other. There are two others that neither conjoin nor disjoin. They merely interfere in the impact of either on the identity of the colonizer and the colonized. The other-other (the colonized) and the proper-other (the colonizer while colonized himself) contend upon the colonizer's identity for the demarcation of the margins of alterity, but in this case alterity is, as it were, on both sides of the margin. This has consequences for two of the core procedures of postcolonial discourse: mimicry and stereotype.

Colonial mimicry is always a lie because, according to Bhabha, it always occurs at the crossroads of what is known and permissible and what is not known and must be concealed (Bhabha, 1994: 89). At the geopolitical level, says Benedict Anderson, this kind of mimicry is what makes empire and nation compatible (Anderson, 1983). Underlying this conception is the supposedly obvious idea that what is at stake in colonial mimicry is the colonized's mimicking of the colonizer. Now, as far as Portuguese postcolonialism is concerned, nothing of the sort is at all obvious and rather needs to be looked into. Mimicry games were in this case far more complex and mutual, and again for the sake of survival. Mimicry practices were much more chaotic because, far from being the purposeful tool of imperial domination, they were often intersubjective contingencies in contexts of difficult survival. They were like a first-aid kit in situations when one could not be easily evacuated by the long, nimble arm of the empire.

For this reason, the "empire's lie," which, according to Bhabha (1994: 138), results from the pretense of integrity and completion in the appropriation of indigenous cultural knowledge, is different in the case of the Portuguese empire. The lie, in this case, often consisted in claiming to be an empire "like the others," while hiding the fear of being absorbed by the colonies, as when the Portuguese crown fled to Brazil and established the empire's capital in Rio. This was an act of representational rupture without parallel in western modernity.

For the same reason, the stereotype of the colonized was never as final as the stereotype in the British empire, or at least it was far more inconsequent and transitory. Sexual penetration converted into territorial penetration, and racial interpenetration gave rise to fluctuating signifiers that equally sanctioned opposed stereotypes, according to origin and intent of enunciation. They sanctioned racism without race or, at least, a "purer" racism than its racial basis. They sanctioned racism as well on the excuse of anti-racism. Thus, the sexist and interracial bed could become the basic unit of the empire's administration, while racial democracy could be waved as an anti-racist trophy in the white, brown, and black hands of racism and sexism.

The fact that the colonizer was colonized in turn does not mean that he was better or more closely identified with those he colonized. Nor does it mean that those colonized by a colonized-colonizer are less colonized than those colonized by a full-fledged colonizer. It simply means that the ambivalence and hybridity noted by Anglo-Saxon postcolonialism are, in the case of Portuguese postcolonialism, way beyond the representations, gazes, and practices of enunciation. They are rather incarnate bodies, daily experiences and survivals that went on for centuries and were sustained by forms of reciprocity between the colonizer and the colonized, unsuspected in the space of the British empire.

In order to explain this difference another one must be introduced concerning games of authority. In postcolonial studies the colonizer always appears as a sovereign subject, the metaphoric incarnation of the empire. Now, as far as Portuguese colonialism is concerned, no such thing can be easily assumed. Only for a very short period-in Africa, since the end of the nineteenth century-does the colonizer incarnate the empire, and only in very selective circumstances. Aside from that, the colonizer only represents himself. $\mathrm{He}$ is an empire of one. As such, he is as free for the excesses as for the deficiencies of colonization. 
Moreover, precisely because his imperial identity is not granted him by anybody beyond his own self, he is indeed as deprived of sovereignty as the colonized. Therefore, authority does not exist beyond the power or negotiation that can be mobilized in the contact zone.

This double ambivalence of representation affects both the identity of the colonizer and the identity of colonized. It may well be that the excess of alterity I identified in the Portuguese colonizer could also be identified in those he colonized. Particularly in Brazil, one could imagine, hypothetically, that the identity of the colonized was, at least in some periods, constructed on the basis of a double other, the other of the direct Portuguese colonizer and the other of the indirect English colonizer. As we shall see, this doubleness became later the constitutive element of Brazil's myth of origins and possibilities for development. It inaugurated a rupture that is still topic for debate. It divides Brazilians between those that are crushed by the excess of past and those that are crushed by the excess of future.

Portuguese colonialism carries with itself the stigma of an undecidability that must be the main object of Portuguese postcolonialism. Has colonization by an incompetent, reluctant, originally hybrid Prospero resulted in undercolonization or overcolonization? A colonization that was particularly empowering or disempowering for the colonized? Mightn't a chaotic, absented Prospero have given way to the emergence of substitute Prosperos in the very bosom of the Calibans? Could it be for this reason that within Portuguese postcolonialism the issue of postcolonialism is less important than internal colonialism? It is no doubt significant that independence, both of Brazil and the African countries, took place in the context of important progressive political transformations in the metropolis: the liberal revolution of 1820 and the April revolution of 1974. This fact, combined with the country's semiperipheral position in the world system, prevented neocolonialism from following the traces left by colonialism, as was the case of British or French colonialism. This is not to say that neocolonialism has not occurred (or will not occur). It seems, however, that neocolonialism exists only in such small countries as Cape Verde, Guinea-Bissau, São Tomé and Príncipe, and Timor, where, given the scale of operations, it can thrive in spite of the deficiencies of the former colonizer. The postcolonial excess of all large former colonies is related to the deficit of the colonialism they suffered.

This deficit of colonialism and neocolonialism helps to explain the specificity of the political forms that emerged with the independence of the large colonies. In opposite directions, these forms swerved from the norm of decolonization established by hegemonic colonialism. In Brazil occurred one of the most conservative and oligarchic independences of the Latin-American continent, and the only one that was a monarchy. The conditions were thereby created for external colonialism to be followed by internal colonialism, for colonial power to be followed by the coloniality of power. In Angola and Mozambique, on the other hand, swerving from the norm materialized in the revolutionary regimes adopted by the new countries, which were thus placed, right in the midst of the Cold War, on the opposite side of the one they had occupied earlier as Portuguese colonies. The vicissitudes these countries have undergone these past twenty-five years (the end of the Cold War, civil war) do not allow us to assess the extent to which internal colonialism will end up characterizing the new countries.

The undecidability and lack of pattern that characterize Portuguese colonialism provoke the following question that should be pondered for the sake of a situated postcolonialism: why did it last so long, much longer than hegemonic colonialism, and why, in the case of the more important colonies, did its end require such a prolonged liberation war? My working hypothesis is that the other colonizer also played a crucial role in this regard. I mean central colonialism that from the nineteenth century onwards followed closely in the footsteps of the Portuguese colonizer. Both in the Berlin Conference and at the end of World War II, the 
conflicts and mutual conveniences of core capitalist countries dictated the continuity of the Portuguese colonial empire. In the latter case, the Cold War and the fact that Africa was left out of the Yalta agreements allowed the core capitalist countries to use Portuguese colonialism as a stopper against the Soviet danger. Given the weaknesses of the Portuguese Prospero, they managed to use him to control Africa and, above all, to protect South Africa without being charged with colonialism. In this way, under a new guise, the identity of the colonized colonizer could be reproduced until the end of the empire. The issue is whether and under what forms this identity is still being reproduced, now that Portugal has earned the periphery of Europe as its rightful place. A periphery, in fact, entitled to the imagination of the center. ${ }^{14}$

The undecidability of Portuguese colonialism provides ample material for inquiry into a situated, contextualized postcolonialism, that is to say, a postcolonialism that won't be trapped into the play of similarities and differences between Portuguese and hegemonic colonialism. Otherwise, some will only see the similarities, some the differences, and between the two undecidability will vanish like one last incommensurate object, as invisible to itself as the gaze. In the present context, situated postcolonialism presupposes careful historical and comparative analyses of the different colonialisms and their aftermaths. One crucial question to be answered is who decolonizes what and why. Only thus may postcolonial discourse account for dissemination as proposed by Bhabha, a discourse that oscillates between different cultural formations and social processes without a central logical cause (1990a: 293). Failing this historic and comparative specification, postcolonialism would be one more form of cultural imperialism, a particularly insidious one at that because credibly anti-imperialist.

\section{Mirror Games, I: A Caliban in Europe}

Identities are the product of mirror games among entities that, due to contingent reasons, define relations amongst themselves as relations of difference and ascribe relevance to such relationships. Identities are always relational but seldom reciprocal. The relation of differentiation is a relation of inequality that hides behind the supposed incommensurability of differences. Whoever has the power to state difference, has the power to declare that difference superior to the other differences reflected in its mirror. Identity is originally a mode of domination based on a mode of production of power that I designate as unequal differentiation (Santos, 1995: 424-428; 2000: 264-269). Subaltern identities are always derived and correspond to situations in which the power to declare difference is combined with the power to resist the power that declares it inferior. In subaltern identity, stating difference is ever an attempt to appropriate a difference stated to be inferior so as to cancel out its inferiority. Without resistance there is no subaltern identity; there is only subalternity.

Dominant identity is thus reproduced by two distinct processes: by totally negating the other; and by vying for the other's subaltern identity. The former leads almost always to the latter. For example, the dominant, matrix-like identity of western modernityProspero/Caliban, civilized/uncivilized-reproduced itself at first by the former and then by the latter process. The two processes continue to be effective in different mirror games. Nonetheless, from the viewpoint of the superior different one, dominant identity only becomes a political fact inasmuch as it contends with subaltern identities. This political fact we nowadays designate as multiculturalism.

In either mode of reproduction, dominant identity is always ambivalent, for even total negation of the other is only possible through the active production of the other's nonexistence. The production implies the desire of the other experienced as an abysmal absence or insatiable lack. The ambivalence can be seen in representations of America at the 
beginning of European expansion. Most reports of the discovery and most travel narratives of the period yield a peculiar mixture of utopian images of the new continent and the indigenous peoples' cannibalistic practices. On the one side, lush and benevolent nature; on the other, repulsive anthropophagy. In "Des Cannibales" (1580), Montaigne was the first one to analyze these two seemingly contradictory images-utopia and cannibalism-as interdependent mechanisms. Revulsion from cannibalism is the other side of the desire for unity with nature and the cosmos, the unity the Europeans had lost and believed the Indians still had (Klarer, 1999).

Concerning identity games in the Portuguese time-space I propose the following hypotheses. First, these games are particularly complex because in the course of history the Portuguese were always on both sides of the mirror: as Prospero reflected in Caliban's mirror, and as Caliban reflected in Prospero's mirror. Second and as a consequence, ambivalence is strengthened in this time-space by the fact that the subject of desire was also the object of desire. Third, the dominant identity in this time-space never accomplished the total negation of the other, thereby failing as well to face subaltern identities in a political manner.

The features invoked by the Portuguese to construct the image of the primitive and savage peoples in their colonies from the fifteenth century onwards are quite similar to those ascribed to themselves at the time by North European travelers, traders, and monks: ${ }^{15}$ underdevelopment and precarious life conditions, sloth and sensuality, violence and affability, poor hygiene and ignorance, superstition and irrationality. The contrast between the north of Europe and Portugal comes across clearly in the report of friar Claude de Bronseval, the secretary of the abbot of Clairvaux, concerning their trip to Portugal and Spain in 1531-1533. They complain of the bad roads, the people's rough manners, and the lousy accommodation and treatment, which are "in accord with the country" (Bronseval, 1970, II: 577). They also resent strange habits such as the fact that noblemen accommodate foreigners in the poorest houses for fear of being considered innkeepers (Bronseval, 1970, I: 431). As to the monks' education, they note that "few of them in these Hispanic kingdoms like Latin. They only love their ordinary language" (Bronseval, 1970, I: 461). The visitors' description of Lisbon could not be more eloquent concerning their general attitude:

This densely populated city is a cavern for Jews, a food board for a crowd of Indians, a dungeon for the children of Hagar, a storage of goods, a furnace for usurers, a stable of lust, a chaos of avarice, a mountain of pride, a sanctuary for runaways, a haven for condemned Frenchmen. (Bronseval, 1970, I: 329)

In Portugal de D. João V visto por três forasteiros [King John the Fifth's Portugal as seen by three foreigners], Castelo Branco Chaves presents three reports written by visitors between 1720 and 1730 . According to Chaves,

The general picture one gathers of the country is that of a fertile, rich land, yet squandered, and living off Brazil's gold almost exclusively. Most of the food and clothing, most timber for urban and naval construction, most of the necessaries of life, all came from abroad, from England and Holland, and purchased with Brazilian gold. The Portuguese are lazy, do not take advantage of their country' riches, nor do they know how to sell their colonies' riches well. (Chaves, 1983: 20)

With the only exception of the final reference to the colonies, this characterization fits perfectly what was then said, and had been said for two centuries, about the indigenous peoples of America and Africa. The Portuguese are said to be jealous, cruel, vindictive, sly, scornful, frivolous, and silly. Now, cruelty, vindictiveness, dissimulation, frivolity, and 
silliness also constitute the European stereotype of African or Amerindian peoples. This is often implicit in the reports themselves when the skin color of the Portuguese is invoked to confirm the truthfulness of the stereotype. According to one of the reports, the Portuguese are "tall, handsome, and generally dark-skinned as a result of their intermixing with blacks" (Chaves, 1983: 24). While the Portuguese claimed miscegenation as a humanistic triumph or a clever colonialist device, the European Prospero's gaze inscribed on their skin miscegenation itself as a burden.

After the second half of the eighteenth century the "black legend" of Portugal and the Portuguese among the British as a fallen, degenerate, and imbecile people becomes more consistent. Among her recordings of English impressions on the Portuguese in the eighteenth and nineteenth centuries, Laura Pires mentions a letter by a certain Captain Richard Croker, dated December 1780, in which the Portuguese are depicted according to the racist stereotypes of the time: extremely ugly, certainly not white, and rather the result of some clearly disgusting ethnic mixture, the Portuguese are said to combine the worst defects of blacks, Jews, Moors, and ... the French. According to another visitor, in 1808 there were no Portuguese books worth acquiring in the country (cf. Pires, 1981: 112; 85).

In her study of the impressions culled by the German Commissary of the British army, August Schaumann, during his stay in Portugal between 1808 and 1814, Maria Teresa Byrne shows that the Portuguese are in general described as peasants and rather primitive. "I pitied these poor devils with all my heart," Schaumann writes, regretting the situation of a people that is invaded by two countries, one attacking (France), the other defending it (England) (Byrne, 1998: 108). About the same time, Lord Byron visited Portugal (1809) and left his impressions in his famed Childe Harold's Pilgrimage (1812-1818). As he expresses his admiration for the natural beauty of the country ("Oh, Christ! It is a goodly sight to see / What Heaven hath done for this delicious land / [ . . ] What beauties doth Lisbon first unfold"), the poet does not spare the Portuguese not only for their arrogant subalternity before invaders (the French) and allies (the British) alike, but also for their swarthy, uncomely appearance and uncouth manners:

A nation swoln with ignorance and pride,

Who lick yet loathe the hand that waves the sword

To save them from the wrath of Gaul's unsparing lord.

$[\ldots]$

But whoso entereth within this town, That, sheening far, celestial seems to be, Disconsolate will wonder up and down, 'Mid many things unsightly to strange ee;

For hut and palace show like filthily:

The dingy denizens are rear' $d$ in dirt; Ne personage of high or mean degree Doth care for cleanness of surtout or shirt; Though shent with Egypt's plague, unkempt, unwashed, [unhurt. (I, Xv-xvii)

At the end of the seventeenth century, however, the Reverend John Colbatch, who occupied the post of chaplain of the British Factory in Lisbon, left a fairer opinion of the Portuguese ("no people less addicted to drunkenness"), while nonetheless noting their "mortal hatred" of "foreigners" and their lack of gratitude for the English "who had been 
with such frequency their saviours" (apud Macaulay, 1946: 224-225). One hundred and fifty years later, Reverend J. M. Neale presented a sorry picture of the "primitive barbarity" and wretched living conditions in the country at the time ("you lie at nights on the boards of inns to which you would hesitate in England to consign a favourite dog"), and warned that "when in a passion the Portuguese become dangerous" (apud Macaulay, 1946: 207-208). The romantic poet Robert Southey visited Portugal for the first time in 1796. Although he claims to have admiration for the Portuguese, Southey nonetheless thrashes them for being a retrograde, superstitious, filthy, lazy, jealous, vain, ignorant, and dishonest people. A people, moreover, palsied by the tyranny of state and church, both of them corrupt and ignorant, and a people at the mercy of astonishing and shocking institutions-justice totally inefficacious and medicine in the hands of ignorant and discredited physicians (Castanheira, 1996: 83). In a sentence that vividly enhances the symmetry with the European stereotypes concerning the indigenous peoples of Africa or America, Southey asserts:

Sensuality is certainly the vice of the Portugueze. The debauched imagery of Camoens, his island of Love, and Venus the protector of Gama, prove they pike themselves on their debaucheries of this kind. (apud Castanheira, 1996: 92)

The symmetry between the North European stereotypes of the Portuguese and the North and South European stereotypes of the indigenous peoples of Africa and America becomes particularly consistent as regards the ambivalence with which the act of stigmatizing the other is mixed with the radical desire of the other. Like Byron, Southey has a harsh view of the Portuguese while at the same time exalting the natural beauties of the country: "I would give one eye to blind Fortune if she would let me look on the Tagus with the other" (apud Castanheira, 1996: 75). The rich fertile, land, yet squandered by its inhabitants, is a recurrent topos in all accounts. Carlos de Merveilleux, the French naturalist physician invited by King John the Fifth to write the "natural history of this reign," reports:

The lands produce almost with no toil and give abundant compensation for their care and tillage. [...] What wealth wouldn't accrue to His Majesty if His estates were peopled by anabaptists and other such hardworking people. (apud Chaves, 1983:20).

The dialectics of foreignness/desire and repulsion/attraction that we find in the description of the animals of the new continent and the Indians' relationship with them, can also be found in the accounts of foreign travelers in Portugal. Dora Wordsworth Quillinan, the poet's daughter and wife of Edward Quillinan, one of the translators of Os Lusiadas, writes vividly of the grotesque emotional attachment that the Portuguese have for their ugly and repugnant pigs (Pires, 1981: 40)

The dialectics of representation of the colonized turns them into attractive and repulsive beings at one and the same time: docile and threatening, loyal and treasonous, angelic and diabolic. Stereotypes, therefore, could never be univocal or consistent. According to the colonizer's representation needs, now negative now positive stereotypes prevail, even though both pertain to each other reciprocally. This dialectic also occurs in representations of the Portuguese by foreigners. Alongside "negative" representations, there are "positive" representations as well. As a matter of fact, as with descriptions of the colonized in colonial narratives, the controversy on the "profile" of the Portuguese among foreign observers was often fierce. Negative stereotypes prevailed after the second half of the eighteenth century as England's ascendancy over Portugal intensified, although closer to us several other narratives emerged, aimed at contesting and offering alternatives to previous narratives, now considered false. Some even try to reconstruct the history of the representations of the 
Portuguese so as to highlight their positive face, as is the case of Rose Macaulay in her two books on reports of journeys to Portugal (Macaulay, 1946; 1990). The stereotype of mild manners, although quite recent, is perhaps the most consistent of them all. It is at the root of an even more recent one: Luso-tropicalism.

\section{Mirror Games, II: A Calibanized Prospero}

In the previous section I showed that the Portuguese were never at home in the European Prospero's original time-space. They lived there as if internally displaced in symbolic regions not their own and where they were not at ease. They suffered applause and humiliation, stigmatization and patronizing, but ever aloof, as if never totally contemporaneous of the time-space in question. Forced to play the game of modern binarisms, it was hard for them to know which side they were on. Neither Prospero nor Caliban, they were left with liminarity and the borderland, and with inter-identity as original identity.

Apparently contradicting all this, Portugal was the first European power to embark in overseas expansion and the one that kept its empire the longest. If colonialism played a crucial role in the system of representation of western modernity, Portugal was pioneer in the construction of this system and hence in the founding mirror game between Prospero and Caliban. Herein lies the enigma: how did the European Caliban manage to become Prospero overseas? Or could it be that, because he never fully assumed either identity, he managed to be both at the same time? Portugal's hegemony in the world system did not last long. By the end of the sixteenth century, Prospero's and Caliban's signifiers were already circulating beyond the control of the Portuguese. The inscription of such signifiers in the systems of representation of the Portuguese were of such complexity and went on for so long that they ended up giving rise to contradictory stereotypes and myths, each of them resonant with half truths. Up until now, the historical construction of the Portuguese discoveries and colonialism has been haunted by myths that reciprocally reinforce and cancel each other. On the one hand, Charles Boxer's construction: The Portuguese as an incompetent Prospero, bearing all of Prospero's faults and none of his virtues. On the other hand, Gilberto Freyre's construction: The Portuguese as a benevolent, cosmopolitan Prospero, willing to make an alliance with Caliban to create a new reality. Bearing in mind the disorder and chaos of the practices they wanted to sort out, these two constructions are both credible. This undecidability corroborates a regime of interidentities. The Portuguese, ever in transit between Prospero and Caliban (hence, frozen in such transit), were both racist-often violent and corrupt, more prone to pillage than to development-and born miscegenators, literally the forefathers of racial democracy, of what it reveals and conceals, and better than any other European people at adjusting to the tropics.

In Africa, Asia, and Brazil, this inter-identity regime had many manifestations, among them "cafrealization" and miscegenation. The two phenomena are related, although referring to distinct social processes. Cafrealization is a nineteenth-century designation used mainly in Eastern Africa to stigmatize the Portuguese men that yielded their culture and civilized status to adopt the ways of living and thinking of the "cafres," the blacks depicted as primitive savages. Portuguese men, we might say, caught in Caliban's snares, or indeed Calibanized, who broke with their original culture and lived their lives in the company of their Caliban women and children according to the local customs.

The designation emerges with this connotation in colonial discourse in a precise moment of the history of Portuguese colonialism. I shall call it "the moment of Prospero." It expresses a practice that spread between the sixteenth and the nineteenth centuries mainly in Africa's eastern coast. It consisted of a prolonged interaction of the Portuguese with the local 
cultures and powers, whose commercial interests could not be sanctioned by any imperial power worth the name and which, for that reason, tended to be characterized by reciprocity and horizontality, if not subordination and vassalage to local sovereigns and authorities. The continued practice of such interactions pushed them beyond sheer commercial activity into deeper kinds of relationships, often including family ties and the acquision of native languages and manners. Including, in a word, cafrealization. In the eighteenth and nineteenth centuries the term "cafre" did not have the negative sense that it acquired later. ${ }^{16}$ It was used only to distinguish blacks (cafres) from the Arab-speaking peoples that had been long engaged with Arab, Muslim, and Swahili traders in the region. The easy interaction between the Portuguese and the local populations and the ensuing hybrid cultural practices are well documented since the seventeenth century. The accounts, often written by priests, criticize these practices, while showing understanding for the difficulties faced in those regions by people with no colonial power to protect them. Here is Friar João dos Santos in his 1606 Etiópia Oriental [Eastern Ethiopia]:

A Portuguese man named Rodrigo Lobo had possession of most of this isle, ${ }^{17}$ which the Quiteve [king] granted him in friendship. The king also bestowed the title of his wife on the man, which was the name that the king called the Captain of Mozambique and Sofala, as well as all the other Portuguese he loved. With this name the king signifies that he loves them and wants them to be honored as his wife is. (Santos, 1999: 139)

Over a century later, in 1766, writes António Pinto Miranda:

[The Europeans in Mozambique] (. . .) marry local ladies and others of Goan descent (. . .) forget their Christian upbringing and do not so instruct their children, who then behave the way I have related concerning our countrymen (...) They take other women besides their wives (.. .) and lazily lie in hammocks days on end, forgetful of death till it comes to claim them. (Miranda, 1954: 64).

In 1844, João Julião da Silva wrote in his Memoria sobre Sofalla [Memoir of Sofala]:

The civilization of this town [Sofala] has not progressed from its primitive state (. ..) its inhabitants were among the greatest criminals and people without morals who were sent here to serve life sentences and settled here (. . .) They quickly familiarized themselves with the cafres (. . .) They wedded black women of the jungle in the cafre way and begot mulattoes, who were raised like cafres, and many to this day do not know how to read and write. (...) They are ignorant even of the rudiments of our Holy Religion, the Portuguese language, and the European manners. (apud Feliciano and Nicolau, 1998: 36)

The act of disqualifying as primitive and savage the indigenous peoples and the Portuguese that mingled with them and adopted their manners occurs frequently in these accounts. ${ }^{18}$ For a long period of time, the prevailing Portuguese stereotype has nothing to do with Prospero, rather with a proto-Caliban, or a cafrealized person. As we get to know better the narratives of these cafrealized Portuguese, we will have a more complex idea of the processes of hybridization, no doubt a different idea from the one that comes to us from the accounts of those who visited the jungle in meteoric apparitions of the imperial power, whether church or crown, otherwise always absent.

The disqualification and stigmatization of the cafrealized Prospero was facilitated by the origin of the Portuguese that peopled the territories. As Marc Ferro states, "the Portuguese were the first ones to get rid of criminals and delinquent by sending them to 
serve sentences overseas - an example that England followed in large scale after 1797 by sending convicts to people Australia" (1996: 179). After 1415, every ship sent to explore the coast of Africa carried aboard its own contingent of deported people. Ignacio Caetano Xavier refers to them in strongly pejorative terms in his account of 1758-1762 (Xavier, 1954: 175176). The subtext of Xavier's account is that the social origin of the Portuguese in Africa called for a stronger colonial authority. Such authority, however, was weak, as we saw, and so inconsistent that it could rather be characterized as an apparitional power.

The apparitional nature of colonial power is, to my mind, crucial to understand the ways of inter-identity in Africa during this period. The fact that Portuguese colonialism in Africa was for centuries more intent on controlling sea trade than settling the territory, in conjunction with the political and administrative weakness of the colonial state, resulted in the fact that the Portuguese engaged in trade in the region were colonizers without a colonial state and therefore forced to practice a kind of colonial self-government. This colonial selfgovernment allowed each and every one to identify themselves at pleasure with the empire's power, but did not provide any other imperial power but what they themselves could procure by their own means. Since the means were scarce, the Portuguese had to negotiate everything, not only trade but also survival itself. The Portuguese "colonizer" was often in the situation of having to pay allegiance to the local king. Since colonialism was nonexistent as an institutional relation, there was a wide gap between the settler, on the one side, and the colonial state and the Empire, on the other. Xavier is quite eloquent on this situation (Xavier, 1954:174-175). The same lack of colonial state often resulted in having several tasks of sovereignty, for example the protection of frontiers, "subcontracted" to local populations, as reported in the eighteenth century "Notícias das Ilhas de Cabo Delgado" [News from the Islands of Cabo Delgado] ${ }^{19}$ (Portugal, 1954: 276).

Likewise, colonial legality, for lack of a strong colonial state to implement it, was less in the hands of those issuing the laws than in the hands of those who were supposed to obey them. Colonial self-government led to the formation of a parallel legality that combined highly selective application of official legality with local legalities or legalities adjusted to local conditions. This may well be the first example of modern legal pluralism. ${ }^{20}$ From the point of view of the Portuguese in the colonies, the juridical status of their activities was neither legal nor illegal; it was a-legal. From the point of view of the crown, it was a system of disobedience that could not be assumed by anyone. It was similar to the system in Spanish America known by the phrase "I obey but do not execute." It was an in-transit [tornaviagem] juridical system. The laws were dispatched from Lisbon, sometimes they would never reach their destination, when they did they were ignored, and when, much later, acknowledged at all the conditions had changed so much that not implementing them was entirely justified. The laws would then be returned to Lisbon, along with the justification of the colonial government and the final vow of obedience: "Waiting for instructions."

Such features of political economy could not but have impact on the inter-identity regime, on the way the Portuguese would cafrealize themselves, that is to say, on the hybrid way in which they mingled with the cultures and practices they had to live with. If this impact is all but obvious, its precise meaning, however, is one of the factors of the undecidability of the system of identity representations in the time-space of Portuguese colonialism. Was cafrealization and, in general, "adaptation to the Tropics," a result of facility or necessity? Did facility make it necessary, or rather necessity make it easy? The facility reading tends to destigmatize cafrealization and render it empowering. Jorge Dias's analysis is a paradigmatic version of this reading: 
The heterogeneous composition of the Portuguese people and their traditional communitarian and patriarchal structure allowed them to assimilate perfectly the Christian spirit of fraternity in a wholly coherent manner, even when challenged by situations of great racial and cultural contrasts (. . .) The Portuguese did not bring along attitudes of conquest; they rather tried to establish friendly relations with the populations of the various continents, and only when necessary were they drawn to the use of arms (. . ) Our assimilationist action was never violent (...) we tried to adjust to the natural and social milieus, with great respect for the traditional ways of life (...) we managed to arouse in the indigenous peoples some respect for certain principles of our western civilization. (Dias, 1961: 155-156)

In this reading, cafrealization is the unsaid that sustains its opposite: assimilation. ${ }^{21}$ Indeed, it is a double unsaid. An unsaid of assimilation because assimilation is inverted: the assimilation of Prospero by Caliban. But also the unsaid of cultural imposition typical of colonization, whether assimilationist or not, because it is a negotiated identity. Curiously enough, in what appears like one more mirror game, this reading is in accord with some of the accounts of foreign travelers in Portugal since the eighteenth century, who were not inattentive to the porosity of identity practices among the Portuguese. The Irish Captain Costigan, who visited Portugal in 1778-1779, expressed astonishment at the pleasant familiarity of the Portuguese towards their servants, something unheard of in England (Macaulay, 1990: 193).

On the contrary, the necessity reading tends to see in cafrealization Prospero's unavoidable weaknesses and incompetence. It appears as the expression of a degeneration whose backwardness drags along the colonized's backwardness. This is largely Charles Boxer's reading, as well as the reading that underlies the colonial policies from the end of the nineteenth century onwards, although, in the latter case, the reading aims exclusively to justify the break with the previous colonial policies.

Miscegenation is another manifestation of the porosity of Portuguese identity regimes. It is not the same as cafrealization and may occur without it. But when the colonialist and racist discourses were more intense-what I call the moment of Prospero-the stigmatization of cafrealization dragged along the stigmatization of miscegenation (miscegenation as cafrealization of the body). I do not deal with this issue in this paper. That miscegenation was the "Portuguese exception" in European colonialism (Ferro, 1996: 177) tends to be rather consensual today, as is the fact that not only the Portuguese practiced it.

The porosity of frontiers between Prospero and Caliban reached its greatest expression of identity in the figures of the mulatto and the mulatta. The ambivalence of their representations is quite significant of the nature of a colonial pact that was as open as devoid of guarantees. Now looked upon as genetically degraded beings, the living expression of treason against Caliban, now looked upon as superior beings, combining what best was there in Prospero and Caliban, mulattoes were, in the course of centuries, a symbolic commodity whose rate varied according to the vicissitudes of colonial alliances and struggles. In periods when Prospero tried to affirm himself as such or when Caliban gained consciousness of his oppression and was ready to fight it, the mulattoes' social rate decreased. On the contrary, it increased in the much longer periods when neither Prospero nor Caliban felt the need or were able to affirm themselves as such. As expression of racial democracy, the mulattoes, without willing it and against their interests, contributed to legitimating racial social inequality. By deracializing social relations, they allowed colonialism to shed their guilt concerning their proper way of producing social inequities: "Black because poor" became the credible alibi for those who acted under the mirror assumption: "Poor because black." 
The conclusion may therefore be drawn that the debate about the sociological political and cultural value of miscegenation is undecidable in its own terms, because it is one of the ersatz debates of the settling of accounts between Prospero and Caliban, a debate as yet undecided between European colonialism and its colonized.

One more tricky aspect of the identity regime of the Portuguese is that the Portuguese may be themselves already miscegenated, that is to say, mulatto to begin with and unable to engender but mulatto men and women, even when they are white men and women. We saw in the previous section that the foreigners who visited Portugal in the course of centuries took the skin color of the Portuguese as a recurrent signifier of distance and disqualification. The skin color becomes part of the scientific narrative of identities at the end of the nineteenth century. The undecidable debate about the racial and ethnic complexion of the Portuguese emerged then. As in the case of the others, what was at stake in this debate was not verification but rather justification. Those who would render the Portuguese as a proper and prosperous Prospero ascribed to them a Lusitanian, Roman, and Germanic ancestry. On the contrary, those that viewed the Portuguese as a reluctant, inconsequent, and cannibalized Prospero ascribed to them Jewish, Moorish, and African ancestry. The controversy is the proof of the fluctuation of the signifiers at the mercy of the justifications in question. The versatility and flexibility of fluctuations stress the possibility of an original hybridization, a kind of autophagic self-miscegenation that precedes and makes possible all the others.

A primordial kind of miscegenation, under the guise of racist signifiers inscribed in the skin color but also in the physical constitution and even in manners, pursued the Portuguese wherever they went. Outside their colonies or former colonies, and particularly in the AngloSaxon world, the Portuguese were often the object of perplexity. Unbelievable either as Prospero or as Caliban, they were the objects of wild taxonomies that are nothing if not manifestations of inter-identity. In 1946, referring to Azorian immigrants in Bermuda, Reverend J. W. Purves wondered in the Bermuda Historical Quarterly: "But WHO are the Portuguese? To which of the world's racial groups do they belong?" His answer characterized the Portuguese as "one of the Latin nations, those dark-whites peopling the northern shores of the western Mediterranean" (Harney, 1990: 113). In the Caribbean and Hawaii, the Portuguese were always considered an ethnic group distinct from the whites and Europeans, halfway between them and the blacks or natives. ${ }^{22}$ In the Caribbean and Hawaii, they were designated as "Portygees" or "Potogees", indentured laborers that came to replace the slaves after abolition and who were therefore not white, but rather one more variety of "coolie men", like the Chinese and East Indians. For the Afro-Caribbean historian Eric Williams, there is nothing strange about describing the ethnic groups that supported the People's National Movement in Trinidad and Tobago as "Africans, Indians, Chinese, Portuguese, Europeans, Syrians (. . .)" (Harney, 1990: 114). Likewise, V. S. Naipul described the post-independence struggle in Guyana as having taken place between six races: Indian, African, Portuguese, White, Mixed and Amerindian (Harney, 1990: 114). In his trip to Trinidad, Miguel Vale de Almeida records from informers of Portuguese descendent (the "potogees"23) that the "elites did not consider them white, at most Trinidad-white, and the nonwhites did not treat them as superior." (Almeida, 2000: 7)

This intermediary status helps to explain the role of Portuguese-descendent Albert Gomes as political leader of Afro and Indo-Caribbean Trinidadians before the 1960's, at a time when political parties were still divided according to ethnic divisions (Harney, 1990: 115). Albert Gomes' ancestors were the "Africanized Portuguese" from the slave harbor of Vera Cruz where, according to António Garcia de Leon (1993), they served as intermediaries and interpreters between the newly arrived slaves and those buying them.

In her research on the migratory fluxes of the Portuguese between 1820 and 1830, Maria Ioannis Baganha finds out that in Hawaii the Portuguese were seen as an intermediary 
ethnic group, superior to the Asians but inferior to white Caucasians (haole) (Baganha, 1990: 288). Early in the next century, the Hawaiian distinguished between the "Portuguese" and "Other Caucasians". This intermediate status, although structurally ambiguous, was quite precise in the local practices. In the work place, the Portuguese were field bosses (lunas) but never head overseers, the latter position being only accessible to haole elites like the Scots. Likewise, Portuguese carpenters earned higher wages than the Japanese, but a Portuguese blacksmith earned half the salary of a Scottish blacksmith (Harney, 1990: 115).

The intermediary racial status of the Portuguese went way beyond labor relations. In an important rape trial in the 1930 s, it was decisive to help reach a compromise. Since the accused were Asian and native Hawaiians, if the composition of the jury were entirely white (haole), the defendants would surely be found guilty; but if the jurors were Asians and native Hawaiians, the opposite could easily happen. The solution was a jury composed of one Portuguese, two Japanese, two Chinese, and one Hawaiian (Harney, 1990: 115).

In the United States the situation was not much different. The Harvard Encyclopedia of American Ethnic Groups (1980) mentions with distress that, as late as 1976, the town of Barnstable in Cape Cod listed its ethnic groups in two alphabetical sequences, one of "whites," another of "nonwhites," namely Finns, Greeks, Irish, and Jews, on the one hand, and blacks, Portuguese, and Wampanoags on the other. According to the same logic, the Ethnic Heritage Program of 1972 described the Portuguese as one of the country's seven ethnic/racial minorities, the others being "Negro, American Indian, Spanish-surnamed American, Oriental, Hawaiian natives and Alaskan natives" (Harney, 1990: 117). In other words, the Portuguese are the only group of European immigrants to whom the European origin is denied. ${ }^{24}$

Of mixed race to start with, calibanized at home by foreign visitors, cafrealized in his own colonies, semi-calibanized in the colonies and former colonies of the European powers, how could this Prospero be a colonizer and colonize prosperously? Can one be consistently postcolonial vis-à-vis such a disconcerting and exasperatingly disqualified and incompetent colonizer?

\section{MirRor Games, III: THE MOMENTS OF PROSPERO}

The most striking feature of the identity of the Portuguese as reflected in the two other relevant signifiers - the foreign visitor and the colonized - seems to be an incomplete union of opposites. The incompleteness of this union has two distinct sides. The first one refers to the regional differences frequently mentioned in a variety of accounts. At the end of the ancien régime, Andrien Balbi mentions the union of opposites ("[the Portuguese] combine the phlegm and steadfastness of the Northern peoples with the brilliant imagination of the southern peoples"), highlighting at the same time the stereotypical regional differences: "the peasants of Estremadura and Alentejo are lazy; the inhabitants of Estremadura are the most polished, those of the Algarve the liveliest, those of Beira the most hard-working, those of Minho the most ingenious and dynamic, those of Trás-os-Montes, although rather uncouth, are very active" (apud Bethencourt, 1991: 500-501). These differences appear even more striking when the Portuguese are seen by the Portuguese themselves. As seen by themselves, the Portuguese recognize themselves as Portuguese only rather late. José Mattoso recounts a "perfectly verisimilar" anecdote about King Dom Luis. Sailing once in his yacht off the northern coast in the late nineteenth century, the King asked some fishermen whether they were Portuguese. "Oh no Sir," they replied, "not us. We come from Póvoa de Varzim" (Mattoso, 1998: 14).

The union-of-contraries concept has another, to my mind more important, side to it. At certain historical moments and under specific pressures, it was possible for the Portuguese to 
assume one of the contraries, even if not necessarily with verisimilitude. Since they are a union of opposites (i. e. Prospero and Caliban), at given moments or contexts the Portuguese may be either predominantly Prospero or Caliban. In this section I deal with the former possibility, what I call the moment of Prospero.

I distinguish two moments of Prospero: 1 . the end of the nineteenth and the first decades of the twentieth century; 2. the April Revolution and integration in the European Union. At any of these moments, Prospero's prevalence in the identity magma of the Portuguese is due to the pressure of external factors that have to do with developed capitalist Europe. The first moment of Prospero occurs after the Berlin Conference, when effective occupation of the territories under colonial dominion becomes a condition to maintain dominion itself. $^{25}$ Once the partition of Africa was accomplished, the industrialized European countries invest the colonial enterprise with an imperial aspect that closely entails the colonies to capitalist development. The capitalist exploitation of the colonies, which presupposes a tight political and administrative control, becomes the other side of the civilizing mission. To secure its presence in Africa, Portugal feels compelled to act as the other European powers, as if the domestic development of Portuguese capitalism made the same kinds of demands, which was not the case at all. This fact does not fail to catch the attention of English historiography, at the service of the British Empire, hence hostile to Portuguese imperialism. Thomas Pakenham's stance, in his The Scramble for Africa, 18761912, is paradigmatic: "Then there was Portugal, half-senile and three-quarters bankrupt, hoarding her ancient possessions in Africa, Angola and Mozambique, more out of pride than any hope of profit" (apud Furtado, 1997: 77).

I do not intend to linger on this period here. I just wish to highlight the identity metamorphoses that occur therein. The major one is the polarization between Prospero and Caliban. It is precisely at this moment that the primitive native emerges, along with the contrapuntal Portuguese colonizer, representative or metaphor of the colonial state. The process by which the natives are lowered to the status that justifies their colonization is the same that raises the Portuguese to the status of European colonizers. The dichotomy between the Portuguese and the crown disappears. The portable empire that the Portuguese carry from now on is not a self-empire, subject to the weaknesses and forces of whoever carries it, but rather the emanation of a transcending force-the colonial state.

The white Portuguese and the primitive natives arise together simultaneously divided and united by two powerful instruments of western rationality: the state and racism. Through the state, the attempt is made to guarantee the systematic exploration of wealth by converting it into a civilizing mission through the transference to the colonies of the civilized metropolitan ways of life-this is the mimetic creation of "little Europes" in Africa that Edward Said talks about (1980: 78). Through racism, the scientific hierarchy of races is obtained both with the help of the social sciences and physical anthropology. The territorial occupation, a good example of which is Portugal's campaign against Gungunhana, aims to reduce the Africans, starting with their kings, to the condition of docile, subordinate subjects. By the same token, successive missions of scientific exploration-such as Santos Junior's eight missions in the 1930s and 1950s-aim to establish and confirm the inferiority of blacks. ${ }^{26}$ Considering the context of prosperization of the Portuguese settler, no wonder the abovementioned forms of hybridity-cafrealization and miscegenation-are stigmatized with particular violence. At the end of the nineteenth century, António Ennes suggests that "cafrealization is a kind of reversion of the civilized man to the primitive state" (Ennes, 1946: 192). In the same way, Norton de Matos, a former governor of Angola and a paladin of assimilationism, cries out against inverted assimilation: "Some Europeans, fortunately in small numbers, circulated among the natives [in 1912], fully adjusted to their uncivilized habits and usages" (apud Barradas, 1992: 54). 
Whereas the Portuguese go from being deported criminals susceptible to cafrealization to the condition of civilizing agents, the natives go from being kings and servants of kings to the condition of the basest bestiality. The Portuguese become "the valiant whites that guarantee the possession of the African land (...), an affirmation of the necessary presence" (Júnior, 1955: 19). In view of the despicable nature of the raw material, the task of the Portuguese is huge. Now the blacks appear bestialized and capable of being domesticated only by the imperial gesture. The violence of this gesture, the brutality of forced labor, is the other face of the bestiality of blacks, the latter perversely justifying the former. ${ }^{27}$ The matter of how difficult it was to force the blacks to work is recounted in an official publication of the Ministry of the Colonies in 1912: "The natives are prone to drunkenness because of the atavism of many generations; they resist manual labor, to which they subject their women; they are cruel and bloodthirsty because they were thus brought up by their milieu; family love and the love of fellow-creatures is not deep set in their souls" (apud Barradas, 1992: 124). The demonization of the colonized reaches paroxysm, however, when referring to women. The black woman is the one deemed responsible for miscegenation, now stigmatized as the major factor of the degeneration of the race. In 1873, António Ennes writes:

Africa charged the black woman with taking revenge on the Europeans, and she, the hideous black woman-all black women are hideous-seduces the lofty conquerors of the Black Continent into the sensuality of apes [. . . and] the brutishness of inferior races, and even the tusks of the quizumbas [hyenas] that dig the cemeteries. (Ennes, 1946: 192)

Between the black man and the white man an insurmountable barrier rises that is at the same time the line that unites them. In this mirror game, the blacks are savage, and because they are savage they tend to think that "we" are the savage ones. This is what José Firmino Sant'Anna, a physician practicing in the river Zambeze valley, wrote in 1911:

In [the natives' eyes], we are the savages, they ascribe to us the worst instincts [. . .] the distrust with which natives receive the physician. [. . .] Incapable of explaining in any other way the blood samples drawn for tests, they think it is for eating. The physician that engages in this practice is viewed by the majority as an anthropophagous. Even the people that served me closely thought that the wine I consumed was blood. (Sant'Anna, 1911: 22)

Cannibalism is a recurrent topic in moments of polarized mirror games between Prospero and Caliban. Here, too, the line that separates abysmally, allows as well for the closest reciprocity. The charge of cannibalism against Africans often had its counterpart in the charge of cannibalism against the colonizers by the Africans. At the beginning of the twentieth century, Henry Junot recorded a colorful anecdote about the cannibalism of the Portuguese among the peoples he studied in the South of Mozambique:

- Nghunghunyane is dead.28 The Portuguese ate him up!

- What are you saying?

- Of course. The Portuguese eat human flesh. Everybody knows that. They have no legs. They're fish. They have a tail instead of legs. And they live in the water.

-Well then, if they're fish and have no legs, how come they fight against us and beat us? 
- Oh! Those who fight against us are young and have legs. [...] They choose one of us and make a little cut in his pinky to see if he is fat enough. If he's not, they shut him up in a big basket full of peanuts and make him eat to fatten him up; when he's fat enough they make him lie down in a redhot oblong pan the size of a man. [. . . . (Junod, 1996, vol. 2: 299-300)

In the face of polarization, effective colonization is a right and a duty. Africa, for Hegel, is not an historical part of the world:

[What] we call Africa remained closed to all relations with the rest of the world; it is the land of gold turned upon itself, the land of childhood, hidden in the dark's night beyond the day of self-conscious history. [...] The truth is Africa is no part of the historical world, it exhibits no movement or evolution, and what in Africa, that is to say, in its northern part may have happened belongs to the Asiatic and European world [...] What we truly mean by Africa is the a-historical and closed up, still wholy confined to the spirit of nature [...]. (Hegel, 1970: 120;129)

Colonization constitutes, therefore, as Ruy Ennes Ulrich argued forcefully in 1909, the natural duty of the "civilized states" and "superior peoples" to guide and instruct the "backward peoples" (Ulrich, 1909: 698). Henry Junod likewise saw colonization as "a duty to perform vis-à-vis the weaker races" (Junod, 1946: 18). This duty, however, could not be fulfilled without violence, as Alberto d'Almeida Teixeira explains in a 1907 "Report on the operations to prolong occupation up to River Cuilo":

[Since] the idea of independence is intuitive in primitive peoples, as is innate in them hatred of the superior race, persuation and catechesis will in principle be almost always sterile and need the support and previous manifestation of force to bear fruit. (apud Barradas, 1992: 128)

Presupposing the dichotomous polarization between the white man and the black savage, this civilizing mission imposes on the colonized a double identity dynamics: anthropology and assimilationism. Colonial anthropology aims to learn the uses and habits of the primitives better to control them politically, govern them, and make them yield taxes and forced labor. The different forms of "indirect rule" that were adopted at the end of the nineteenth century in Africa are based on colonial anthropology. Assimilationism is a construction of identity based on a game of distance and proximity of the colonized vis-à-vis the colonizer, according to which, the colonized - through procedures that have similarities with the process of naturalization-sheds the savage state. The subordination of the colonized is then no longer inscribed in a special juridical statute (such as, for example, the "Estatuto do Indigenato" [Indigenousness Statute]), and is rather ruled by the general laws of the colonial state. The assimilated thus become the prototype of blocked identity, an identity somewhere in between the African roots, to which they stop having direct access, and the options of European life, to which they have but a much restricted access. In other words, the assimilated imply an identity constructed upon a double de-identification.

Assimilationism, together with miscegenation, is what confers to the African society its distinct heterogeneity. In 1952, Alexandre Lobato wonders:

And what does one observe in the Mozambican population? A few million blacks in primitive state, a few thousand civilized whites, a few thousand largely semiEuropean and semi-primitive mulattoes, a few thousand Indians divided into two very distinct groups for ancestral reasons, and a few assimilated, civilized, Europeanized blacks. [...] There is no Mozambican people in the sense we speak 
of the Portuguese people. [...] There is no collective thought in Mozambique. (Lobato, 1952:116-17)

The maximum of possible consciousness of the colonial thought is to regret that the colonized peoples are precisely that into which the colonial policies have transformed them.

The Portuguese moment of Prospero at the turn of the nineteenth century was an excessive moment vis-à-vis its conditions of possibility. Strongly conditioned by the international pressures following the division of Africa, the Portuguese colonizer was nonetheless unable to break totally with the historical long duration of inter-identity between Prospero and Caliban. And so he proved to be an inconsequent and underdeveloped Prospero. In a classified report dated March 6, 1915, Norton de Matos, then outgoing general governor, wrote with chilling colonialist distance of the total inability of the Portuguese to occupy and control Angola (Barradas, 1992: 132).

A few years earlier, Oliveira Martins expressed the same preoccupation, stressing that "plantation colonies were never made with freedom and humanity" (Martins, 1904: 234). In another passage, Oliveira Martins' discouragement at the Portuguese colonizer's lack of conditions to colonize with competence is even more striking:

To hold a gun - with no trigger-in one's hand, to be upon the walls of a decrepit fortress, with a custom-house and a Palace where vegetate badly paid employees, to be helpless witness to the trade foreigners engage in and we cannot, to expect attacks of blacks everyday, and to hear the scorn and contempt with which all travelers in Africa refer to us-honestly, it's not worth it. (Martins, 1904: 286)

Prospero's incapacity to assume himself as such is witnessed not only by colonial administrators but also by foreigners and assimilated. In 1809, Captain Tomkinson briefs Vice-Admiral Albermarble Bertie about the Portuguese of Mozambique:

The soil appeared rich, abundance of tropical fruit. [ . . ] but the plantations [...] have more the appearance of belonging to a poor uncivilised native than a European. [...] they only grow fruit and a sufficiency of Indian corn and rice for their own consumption. [... ] (1964: 4-5). (Tomkinson, 1964: 4-5)

Years later, in 1823, Captain W. F. W. Owen writes in a letter that the "decadence" that follows the Portuguese everywhere is the "natural consequence of their narrow and miserable policy" (Owen, 1964: 34).

About the same time, in 1918, the German naturalists Spix and Martius visiting Brazil contrast the Europeans with the Portuguese, the latter said to be more vulnerable to the "moral degeneration" of the settlers in the Tropics; these settlers showed "lack of diligence and indisposition towards work" and revealed a general decadence, resulting from "lack of upbringing and respect in their intercourse with the house slaves, because they were not used to them in Europe" (Lisboa, 1995: 182-183).

Equally caustic is the assessment of the colonizer by the assimilated in a moment of Prospero. This is what João Albasini writes in 1913 about the suburban white man:

In a dark stinky hut, a greasy counter, a few casks of the stuff, cans of sardines, dark benches, flies fluttering and [. . . ] lots and lots of trash. On the other side of the counter, a hairy and bearded creature moves with some difficulty, now and then casually glancing at the sordidness of the things that guarantee his bliss, the bread, and the dough. This is molungu, this is the gentle soul of colonization. (Albasini, 1913) 
Like a curse, the Portuguese Caliban pursues the Portuguese Prospero, following in his footsteps and carnivalizing his stance as if it were a petty mimicry of what he wants to be.

The second moment of Prospero occurs in the context of the April Revolution and the end of the colonial wars, the recognition of the liberation movements and the independence of the colonies, and continues in the establishment of relations of cooperation with the new countries whose official language is Portuguese and the creation of the Community of Portuguese Language Countries (CPLP) in 1996. This is the moment of an anti-colonial or decolonizing Prospero, a moment similar to the one experienced by the other European colonial powers almost three decades earlier. The end of colonialism was a moment of Prospero inasmuch as the colonial powers, facing the inordinate political costs of maintaining the colonies, looked for a new and more efficient form to reproduce domination over them in the recognition of their independence. This became known as neocolonialism. The colonized Caliban turned into the underdeveloped or developing country. The identity regime was thereby significantly changed, but the underlying political economy was not changed with like intensity. On the contrary, the economic and political ties with the former colonial powers continued to be decisive to the newly independent countries. Paradoxically, Caliban disappeared so that Prospero could survive.

Once again, the moment of the decolonizing Portuguese Prospero differs significantly from the equivalent moment of the European Prospero. First, the two historical decolonization processes, the independence of Brazil and the independence of the African colonies, occurred concomitantly with profound progressive transformations in Portuguese society, the liberal revolution in the first case, and the April revolution in the second. As a result, in both decolonization processes there is a shared sense of liberation, both for the colonizer and the colonized. This shared sense created a certain complicity between the Portuguese political class and the political class of the new countries, particularly in the case of the African independences.

The most decisive consequence of the simultaneous ruptures was that, together with Portugal's semiperipheral position in the world system, they helped to minimize the neocolonialist effects of the post-independence period. In Brazil's case, the neocolonialist incapacity of the Portuguese Prospero expresses itself in panic before the consequences of the loss of Brazil. Actually, Brazil played the role of "colonizing colony," in Marc Ferro's words, when it sent to Angola the largest contingent of white immigrants (1996: 179). Angola, in fact, had been long economically dependent on Brazil. According to Marc Ferro, the Portuguese minister Martinho de Melo e Castro would complain in 1781 that commerce and overseas trade were escaping Portugal entirely "since what the Brazilians do not control is in the hands of foreigners" (Ferro, 1996: 180). ${ }^{29}$

The colonial weakness and incompetence of the Portuguese Prospero did not make neocolonialism possible, but by the same token it facilitated, particularly in the case of Brazil, the reproduction of colonial relations after the end of colonialism-what is known as internal colonialism. As a consequence, among the elites that went on exerting dominion in their own name a difference emerged on their historic responsibilities and how to share them with the former colonizer. They differed, basically, on whether the incompetence of the elites to develop the country mightn't be the result of the incompetence of the Prospero they had just gotten rid of. Would Prospero's incompetence turn out to be a heavy legacy, an insurmountable constraint of the possibilities of postcolonial development or, on the contrary, an unsuspected opportunity for alternative forms of development?

The controversy between Iberianists and Americanists in Brazil (e.g. between Oliveira Vianna and Tavares Bastos) must be understood in this light. According to the Iberianists, the backwardness of the Latin-American society could be transformed into an asset- the 
possibility of a non-individualist and non-utilitarian development, based on a communitarian ethic to which the rural world could be witness. According to Oliveira Vianna, Brazilian uniqueness was less a product of the history of the metropolis than of the specificity of the social relations prevailing in the agrarian world, where an aristocratic class held a particularly aggregating power (Vianna, 1997: 162). On the contrary, Tavares Bastos saw in the legacy of the Iberian political culture and its atavistic anti-individualism the very foundation of the obscurantism, authoritarianism, and bureaucraticism of the Brazilian state. Tavares Bastos maintained, therefore, that it was necessary to break with such legacy and create a new social model, a yankee Hispanic-American social model having as its referent the North American society, its industry, and education. Tavares Bastos went so far as to make the Iberian Prospero's incompetence quite explicit: because Portugal did not have the strength of the Northern countries, it permitted "the general depravation and barbaric roughness of Brazilian manners [to end up prevailing] against the imposition of Portuguese culture" (Vianna, 1997: 157). In other words, Prospero's deficiencies alone made Caliban's excesses possible.

In the case of Africa, the historical assessment of the Portuguese colonial Prospero is still to be made. Moreover, it is not yet possible to judge properly the persistence of neocolonialist consequences, particularly after Portugal became part of the European Union. The trials that the CPLP has undergone illustrate well the weaknesses of the Portuguese Prospero. Unlike the English and French Prosperos in their respective commonwealths, the Portuguese Prospero has not been able to impose his hegemony. Not only has he contended for hegemony with his former colony-Brazil; he has also been unable to prevent some of the new countries from integrating "rival" language communities, as is the case of Mozambique and Guinea-Bissau. Since the hegemony of the latter communities has amounted to the legitimation of neocolonialism, the weakness of the Portuguese Prospero opens enormous potentialities for democratic and truly postcolonial relationships. Whether the former colonizer will be able to transform such weakness into strength, and whether the former colonized are interested in that at all, is, however, an open question.

\section{INTER-IDENTITIES: TOWARDS A SitUATEd POSTCOLONIALISM}

If ever Prospero disguised himself as Caliban, it was with the mask of the Portuguese. Semi-colonizer and semi-colonized and incapable of creating adequate rules to meet their complex situation, the Portuguese were unable to govern their colonies efficaciously, and were therefore unable as well to prepare their emancipation orderly. The colonial war in Africa best demonstrates this double incapacity. Furthermore, no other colonies and former colonies were ever so autonomous vis-à-vis the colonizer and former colonizer. No other colonial power transferred the capital of the Empire to its own colony, nor was ever in any other country such anxiety about the ascendancy of the colony. Portuguese colonization thus emerges as a chaotic process which, by repeating itself across centuries, ended up becoming a kind of order. Either because of lack of competence or power, Portuguese colonialism was often confused with solidarity, allowing for pockets of non-imperial relations inside the Empire itself.

Gradually, the absence of a pattern and this oscillation between a Prospero in Caliban's shoes and a Caliban longing for Prospero, consolidated to give rise to one the characteristics of Portuguese identity, perchance the most intrinsically semiperipheral of them all. We might call it, after sports newsmen commenting on the uneven performance of the national soccer team, "oito-oitentismo" (up-and-downism). Oito-oitentismo, while being a pattern, is the absence of a pattern as well. It intimates a form of identity that lives permanently in a turbulence of scales and perspectives, trivializes extremes, be they exalting or insignificant, 
and never radicalizes anything except the radical option of never to make radical options. The turbulence of scales and perspectives results in a devouring presentification wherein the palimpsests that we are gain a disconcerting contemporaneity: everything appears as contemporaneous with everything else. The attitudes and behaviors contained in this form of identity predispose to forms of representation and performance which do away with proof, that is to say, forms characterized by sheer emergence, by their apparitional nature, with no other justification for being than their post-factum evidence. Dispensing with proof, emergence, and contingency became particularly common from that moment, as early as the seventeenth century, when the history of European expansion stopped being written by the Portuguese. From then on, the Portuguese were caught in the binarisms of hegemonic colonialism, such as subject/object, civilized/uncivilized, culture/nature, human/animal. But all these binarisms were experienced at a distance, through impure scales and "curious perspectives," in the sense of post-renaissance painting (Santos, 2000: 233). Thus, binarisms were carnivalized as abstract zones where everything is proportionate to its own disproportion.

In the absence of pure and peremptory criteria and conclusive reasons, the Portuguese Prospero was not able to present an opulent menu of imperial identities. Being neither an emancipatory nor an emancipated identity, he oscillated between Prospero and Caliban as if in search of Guimarães Rosa's third margin of the river. As such, it was impossible to consolidate essentialisms, and these were mentioned only, if at all, to be contested, thus revealing their intrinsic contingency. The colonies were now colonies, now overseas provinces; miscegenation was seen now as the degradation of the race, now as its most exalting feature; and the indigenous peoples were now savages, now national citizens.

Prospero's instability, imperfection, and incompleteness rendered problematic his selfidentification, a condition that ended up dragging Caliban along as well. A non-ostentatious Prospero convoked a pedestrian Caliban. In the absence of pure criteria, there is no greatness, but when such criteria, rather than lost, were never there, there is no pettiness either. When the enemies do not let themselves be measured, they are neither great nor petty, thus destabilizing the struggles against them. A Prospero so diffuse as to be confused at times with Caliban could not but confound the latter, upset his identity, and block his emancipatory will. The difficult calibration of Prospero's dimension and real stature and identity made Caliban run the risk of being colonialist in his eagerness to be anti-colonialist, and at the same time allowed him more than anyone else to be pre-postcolonialist within the formal constancy of colonialism. The informal colonialism of an incompetent Prospero saved large sectors of the colonized peoples for a long period of time from living Caliban's experience daily, and let some of them (and not just in India) conceive of themselves as the true Prospero and act as such in their domains. They were often allowed to negotiate the administration of the territories and its rules with the European Prospero almost on an equal footing.

How difficult it is to conceive of postcolonialism in the space of official Portuguese language, is confirmed by the above. To my mind, in this space postcolonialism must paradoxically focus on the weaknesses of the Portuguese Prospero. Two guidelines appear to me to be decisive. The first one concerns internal colonialism and is particularly relevant in the case of Brazil. The internal weakness of Portuguese colonialism made possible the conservative independence of Brazil. The oligarchic elites were allowed to cash in on the structures of colonial domination while singing the praise of the inaugural act of the construction of the national state. Internal colonialism is the great continuity in this space. The first guideline instructs us to aim the postcolonialism of the Portuguese language at this internal colonialism. To what extent internal colonialism exists or is emerging in Africa's former colonies, particularly in Angola and Mozambique, is still an open question. 
The second guideline has to do with counter-hegemonic globalization. It concerns Prospero's external weakness, that is to say, the fact that Portuguese colonialism was from the start prey to hegemonic colonialism, mainly in its English version, and prey as well to the forms of imperialism into which it translated itself until its latest avatar in our time, namely neoliberal globalization presided over by the United States of America. Actually, these imperial forms are responsible today for the consolidation of internal colonialism in countries formerly under Portuguese colonialism. The second guideline, therefore, is that postcolonialism must be aimed at hegemonic globalization and the new constellations of local/global, internal/external domination that it gives rise to. From the point of view of postcolonialism, it is today as senseless to wave the anti-Spanish flag in Cuba or Colombia as to wave the anti-Portuguese flag in Brazil or Mozambique.

Bearing in mind these two guidelines, the conclusion must be drawn that postcolonialism in the Portuguese space is very little post- and very much anticolonialism. The struggle is not against a past present but rather against a present past. It is, moreover, a deterritorialized postcolonialism because aimed at a mechanism of social injustice, domination, and oppression that does away with the modern binarisms that have been so far the basis of postcolonialism: local vs. global, internal vs. external, national vs. transnational. Indeed, this different kind of postcolonialism makes sense only inasmuch as it is a struggle for a counter-hegemonic globalization, that is to say, the search of new local/global alliances among different social groups oppressed by the different kinds of colonialism.

It must be borne in mind, nevertheless, that the Portuguese Prospero, however reluctant, incompetent, incomplete, and calibanesque, at the same time that he grounds this progressive postcolonial attitude, renders its fulfillment difficult, in that it tends to conceal or naturalize power relations. Inasmuch as he is an incomplete Prospero, the world he created is the same world that created him. The power of creation thus appears shared by a calibanized Prospero and a prosperized Caliban. Herein lies the arrogance and legitimacy of the postindependentist oligarchic elites. A content analysis of some recent Brazilian formulations concerning the celebrations of the $500^{\text {th }}$ anniversary of the discovery of Brazil reveals the emphasis given to the plurality of peoples that went there, besides the Indians that were already there and the Africans that were forced to go: Italians, Germans, Spanish, Chinese, Japanese, Portuguese, and so on. Side by side with the other immigrants, the reluctant Prospero gets dissolved in the crowd. Again, for being so similar, he goes unnoticed. And yet, this equation conceals that, at least until independence, the Portuguese were not a group of immigrants amongst others and that the colonial power that they protagonized, however specific, was nonetheless colonial. By emptying out Prospero, this representation of the rainbow nation also empties out the relations of colonial power, and turns the discovery into a plural, non-imperial act, an exercise of fraternity and intercultural and interethnic democracy. This concealment may well foster the laziness of the anti-colonial will and the neutralization of the emancipatory energies. There is reason to suspect, therefore, that the elites are far from being naïve when they promote such representations.

Now too close to be noticed, now too telescopic to be seen by the naked eye, this coy Prospero invites complacency vis-à-vis the power of elites, seemingly rendered powerless because of Prospero's powerlessness. The difficulties in developing postcolonial strategies in the space of Portuguese colonialism are, thus, the other side of the ample possibilities for counter-hegemonic globalizations created by this type of colonialism. 
NOTES

This essay would not have been possible without the collaboration of three fine research assistants, to whom I am deeply indebted: Maria Paula Meneses, Maria José Canelo, and Ana Cristina Santos. My thanks as well to Maria Irene Ramalho for her critical comments on my obssessive dealings with Portuguese identity in the course of years; I am also grateful to her for her help in preparing the English version of this essay. A larger version appeared in Entre ser e estar. Raizes, percursos e discursos da identidade. Ed. Maria Irene Ramalho and António Sousa Ribeiro (Porto: Afrontamento, 2001).

${ }^{1}$ For a different view of the world system under hegemonic globalization see Castells, 1996.

${ }^{2}$ On Portugal's place in Africa's colonial cycle, see Fortuna, 1993: 31-41.

${ }^{3}$ Some historians, such as Isaacman (1976), describe the Portuguese colonial system as an "informal Empire," that is to say, an imperialism without a specific colonial government.

${ }^{4}$ As Carlos Fortuna has eloquently shown, these games of temporality manifest themselves extemporaneously vis-à-vis hegemonic time, be it the moment of colonization or decolonization (Fortuna, 1993: 41).

${ }^{5}$ I resort to the names of Prospero and Caliban in Shakespeare's play The Tempest (1611) to signify that the zone of colonial contact appears as a contact zone between the "civilized" and "uncivilized." The notion of hybridization between colonizer and colonized is not original in postcolonial studies. It was perhaps first formulated by Gandhi, who called frequently attention to the continuity between the oppressor and the victim. On this issue, see Santos, 1995: 516; 2000: 351.

${ }^{6}$ Cf. Mondlane (1969) and Anderson (1983).

${ }^{7}$ For a more detailed analysis of the national question in Africa in relation to the emergence of the new independent states, see Mazrui and Tidy (1984).

${ }^{8}$ On the Subaltern Studies Group, see Santos, 1995: 515; 2000: 350.

${ }^{9}$ In more recent work, Gilroy offers a more inclusive approach to the diaspora question. According to Gilroy, the diaspora identity has a crucial dimension in migration that accounts for the production of a "double consciousness" resulting from the fact that the new identity does not entirely assimilate the culture of the country of immigration, nor does it entirely preserve the cultural references of origin. (Gilroy, 2000).

${ }^{10}$ In an important book that came to my attention only after I had completed this essay, Walter Mignolo (2000) argues that postmodernism does not lie outside the modernist canon; rather, together with Marxism, deconstruction, and world-system analysis, postmodernism is a critical discourse within "hegemonic cosmologies." I agree with him, the question being, can we say the same about my "oppositional postmodernism"? This is a topic for future research.

${ }^{11}$ The instrumental nature of tradition has been the object of a variety of studies. See, for example, Ranger (1988), Bazin (1990), and Nandy (1999).

${ }^{12}$ When I defined Portuguese culture as a frontier culture, however, I used the concept of frontier in the sense of contact zone or borderland. For an analysis of this cultural formation, see Santos, 1994: 132-136.

${ }^{13} \mathrm{Cf}$. also Miguel Vale de Almeida's interpellation of postcolonialism from the viewpoint of anthropology (2000: 230ss.). To my mind, the interpellation is not much different if made from the viewpoint of sociology.

${ }^{14} \mathrm{On}$ the concept of imagination of the center, both in the sense of imagining the center and imagining how the center imagines itself, see Santos, 1993: 49. 
${ }^{15}$ By "North Europe" is meant here the Europe considered "civilized." In other words, countries like England, France, and Germany that will have later a decisive role in colonization.

${ }^{16}$ The term "cafre" derives from the Arabic kafr used to refer to the non-Muslim or nonbeliever. On Arabs and blacks in Portuguese Africa, see also Monclaro, 1899: 167, 170.

${ }^{17}$ Located in Sofala, Mozambique.

${ }^{18}$ At the end of the eighteenth century, Ignacio Caetano Xavier comments that the "cafres" are "enemies of work," use skins of animals and trees for garb, and do not engage in agriculture "more than they need for their daily sustenance" (Xavier, 1954:177-178).

${ }^{19}$ Located in the most northern part of Mozambique, these islands are known today as the Quirimbas Archipelago.

${ }^{20}$ On legal pluralism, see Santos, 1995: 112-122.

${ }^{21}$ In Mozambique, assimilation policies were introduced as part of the colonial political system at the beginning of the twentieth century (1917). From then on, the distinction between natives and non-natives was reinforced. As lower class citizens, the assimilated (blacks, Asians, and mixed) held ID's that distinguished them from the mass of nonassimilated workers, who held a native pass. Natives, who were the majority of the population, were not entitled to citizenship or rights, were badly paid and exploited, received but rudimentary instruction, were subject to forced labor, liable to penal deportation, and so and so forth. For example, when in 1950 Eduardo Mondlane arrived in Lisbon to register at the university, his application was not immediately accepted. The problem was that he was not assimilated, had no Portuguese ID, and was not a citizen (Manghezi, 1999).

${ }^{22}$ This intermediary social and ethnic status can be observed in other continents. In South Africa, for instance, Afrikaans designated the Portuguese pejoratively as wit-kaffirs (white blacks) (Harney, 1990: 116).

${ }^{23}$ The designation varies. Harney mentions "Portygees" and "Potagees."

${ }^{24}$ Maria Ioannis Baganha, while not contesting these data and the existence of racism against the Portuguese, mentions that some racism was addressed as well to other groups of Europeans, namely from Eastern Europe. She also emphasizes, however, that the Johnson Act of 1924 and the National Origins System of 1927 restricted entrance in the US of "nonassimilatable" groups, amongst which were the Portuguese (Baganha, 1991: 448).

${ }^{25}$ Among other resolutions, the Berlin Conference decided that a country was entitled to a given overseas territory only if it actually occupied said territory and governed it in such a way as to guarantee individual rights, freedom of trade and religion, and the establishment of civilizing missions.

${ }^{26}$ On the supposed insensitivity of blacks to pain, see Santos Júnior and Barros, 1950: 619.

${ }^{27}$ According to Rodrigues Júnior, "there is no doubt that whites are not prepared to perform certain functions in Africa. For instance, they do not endure physically the hardships of the hoe" (1955: 22-23). Quoting Marcelo Caetano, the author adds that "the blacks have conditions of natural resistance and adaptation to the environment that allow them to perform certain activities in tropical climates in far better conditions than the Europeans [. . .] It is necessary to force [the blacks] to give their contribution to the development of common wealth; they must be forced to produce [. . .] The blacks must be protected and integrated in Mozambique's economic system" (1955: 22-23).

${ }^{28}$ The story refers to the King of the Changane, who was deported to Portugal after being defeated in Mozambique by the Portuguese troops at the end of the nineteenth century, during the so-called "pacification campaigns."

${ }^{29}$ Until the eighteenth century, Mozambique was under the rule of the Viceroy of India. As a consequence, the economic system was largely dominated by Indians. In 1679, António 
Lobo da Silva complained against the canarins (pejorative term for people originally from India) for "robbing" and "ruining" the Portuguese. Much better to renounce their contracts and get rid of them, Lobo da Silva recommended to the authorities in the metropolis, and then have the territories adequately populated by Portuguese settlers (Arquivo Histórico Ultramarino, 3, 77).

\section{WORKS CITED}

Ahmad, Aijaz (1995), "The Politics of Literary Postcoloniality," Race and Class, 36(3), 120.

Albasini, J. (1913), “Amor e Vinho (idílio pagão)," $O$ Africano (Lourenço Marques), $11 / 6 / 1913$.

Almeida, F. J. Lacerda e (1889), Documentos para a História das Colónias Portuguezas. Diário da viagem de Moçambique para os rios de Senna. Lisboa: Imprensa Nacional.

Almeida, Miguel Vale de (2000), Um mar da cor da terra. Raça, cultura e política da identidade. Oeiras: Celta.

Anderson, Benedict (1983), Imagined Communities. Reflections on the Origin and Spread of Nationalism. London: Verso.

Baganha, Maria Ioannis (1990), Portuguese Emigration to the United States, 1820-1930. New York/London: Garland Publishing, Inc.

Baganha, Maria Ioannis (1991), review of David Higgs (ed.), Portuguese Migration in Global Perspective. Toronto: The Multicultural History Society of Ontario, 1990, Análise Social, XXVI(111), 443-449.

Barradas, Ana (1992). Ministros da noite - Livro negro da expansão portuguesa. Lisboa: Antígona.

Bazin, Jean (1990), “A chacun son Bambara,” in J.-L. Amselle; E. M'Bokolo (eds.), Au coeur de l'éthnie.Ethnie, tribalisme et Etat en Afrique. Paris: La Découverte, 87-127.

Bethencourt, Francisco (1991), "A sociogénese do sentimento nacional," in A Memória da Nação. Lisboa: Sá da Costa, 473-503.

Bhabha, Homi K. (1990a), "DissemiNation: Time, Narrative, and the Margins of the Modern Nation," in H. K. Bhabha (ed.), Nation and Narration. London/New York: Routledge, 291-322.

Bhabha, Homi K. (1994), The Location of Culture. London: Routledge.

Boëtsch, Gilles; Savarese, Eric (1999), "Le corps de l'africaine: érotisation et inversion," Cahiers d'Études Africaines, XXXIX (153), 123-144.

Boxer, Charles R. (1963), Race Relations in the Portuguese Colonial Empire, 1415-1825. Oxford: Clarendon Press.

Bronseval, Frère Claude (1970), Peregrinatio Hispanica 1531-1533. Paris: Presses Universitaires de France et Fondation Calouste Gulbenkian.

Byrne, Maria Teresa Real (1998), "As tropas aliadas anglo-portuguesas vistas por um alemão," Revista de Estudos Anglo-Portugueses, 7.

Byron, George Gordon Lord (1966), The Poetical Works. London: Oxford University Press.

Cabral, Amílcar (1974), Guiné-Bissau. Nação africana forjada na luta. Lisboa: Publicações Nova Aurora.

Castanheira, Zulmira (1996), "Robert Southey, o primeiro lusófilo ingles," Revista de Estudos Anglo-Ingleses, 5.

Castells, Manuel (1996), The Rise of the Network Society. Cambridge: Blackwell.

Césaire, Aimé (1983), Cahier d'un retour au pays natal. Paris: Présence Africaine.

Césaire, Aimé (1989), Discours sur le colonialisme. Paris: Présence Africaine. 
Chabal, Patrick (1997) Apocalypse Now? A Post-Colonial Journey into Africa. Inaugural lecture, delivered on 12 March 1997 in King's College, London. (http://www.kcl.ac.uk/depsta/humanities/pobrst/pcpapers.htm, acedido em $10 \mathrm{de}$ Outubro de 2001)

Chatterjee, Partha (1986), Nationalist Thought and the Colonial World. A Derivative Discourse? London: Zed Book.

Chaves, Castelo Branco. (1983), O Portugal de D. João V visto por três forasteiros. Lisboa: Biblioteca Nacional.

Dias, Jorge. (1961), Os elementos fundamentais da cultura portuguesa. Lisboa: Junta de Investigação do Ultramar.

Ennes, António (1946), Moçambique. Relatório apresentado ao governo. Lisboa: Imprensa Nacional [1873].

Fanon, Frantz (1961), Les damnés de la terre. Paris: Maspero.

Fanon, Frantz (1965), The Wretched of the Earth. New York: Grove Press.

Feliciano, J.F.; Nicolau, V.H. (eds.) (1998), Memórias de Sofala por João Julião da Silva, Herculano da Silva e Guilherme Ezequiel da Silva. Lisboa: Comissão Nacional para os Descobrimentos Portugueses.

Ferro, Marc (1996), História das colonizações. Lisboa: Estampa.

Fortuna, Carlos (1993) O Fio da meada. O algodão de Moçambique, Portugal e a economia-mundo (1860-1960). Porto: Afrontamento.

Freyre, Gilberto (n.d.), O mundo que o português criou. Lisboa: Livros do Brasil.

Freyre, Gilberto (1947), Interpretação do Brasil. Aspectos da formação social brasileira com o processo de amalgamento de raças e culturas. Rio de Janeiro: Livraria José Olympio.

Furtado, Filipe (1997), "Portugal em histórias de Inglaterra," Revista de Estudos AngloPortugueses, 6.

Gilroy, Paul (1993), The Black Atlantic: Modernity and Double Consciousness, Cambridge, Mass.: Cambridge UP.

Gilroy, Paul (2000). Against Race. Imagining Political Culture beyond the Color Line. Harvard: Harvard UP.

Hall, Stuart (1996a), "New Ethnicities," in David Morley et al. (eds.), Stuart Hall: Critical Dialogues in Cultural Studies. London/New York: Routledge [1989].

Hall, Stuart (1996b), "When Was 'the Post-Colonial'? Thinking at the Limit," in Ian Chambers; Lidia Curti (eds.), The Post-Colonial Question: Common Skies, Divided Horizons. New York: Routledge, 242-259.

Harney, R. T. (1990), ""Portygees and other Caucasians": Portugueses Migrants and the Racialism of the English-Speaking World," in D. Higgs (org.), Portuguese Migration in Global Perspective. Toronto: The Multicultural History Society of Ontario, 113-135.

Hegel, G. W. F. (1970), Vorlesungen über die Philosophie der Geschichte. Eds. Eva Moldenhauer e Karl Markus Michel. Frankfurt am Main: Suhrkamp.

Isaacman, A. (1976), A tradição da resistência em Moçambique. O vale do Zambeze, 1850 1921. Porto: Afrontamento.

Júnior, José F. (1955), Narração do distrito de Tete, contada por José Fernandes Júnior "O Chiphazi". Maputo: Arquivo Histórico de Moçambique (mimeo).

Júnior, Rodrigues (1955), O Negro de Moçambique (estudo). Lourenço Marques: África Editora.

Junod, Henry (1996), Usos e costumes dos Bantu. Maputo: Arquivo Histórico de Moçambique, 2 volumes [1917].

Junod, Henry (1946), Usos e costumes dos Bantos. A vida de uma tribo sul-africana. Lourenço Marques: Imprensa Nacional, 2 volumes. 
Leon, António Garcia de (1993), "Contrapunto entre lo Barroco y lo Popular en el Veracruz Colonial." Comunicação apresentada no Colóquio Internacional Modernidad Europea, Mestizaje Cultural y Ethos Barroco, Universidad Nacional Autonoma de México, 17-20 de Maio.

Lisboa, Karen Macknow (1995), A Nova Atlântida ou o Gabinete Naturalista dos Doutores Spix e Martius. Natureza e civilização na Viagem pelo Brasil (1817-1820). São Paulo: Universidade de S.Paulo (M. A. dissertation)

Lobato, Alexandre (1952), Sobre cultura moçambicana. Lisboa: Gradiva.

Macaulay, Rose (1946), They Went to Portugal. Oxford: Alden Press.

Macaulay, Rose (1990), They Went to Portugal Too. Manchester: Carcanet.

Manghezi, Nadja (1999), "Eduardo Mondlane nos Estados Unidos da América (19511961)," Estudos Moçambicanos, 17.

Maravall, José Antonio (1990), La cultura del barroco. Análisis de una estructura histórica. Barcelona: Ariel.

Martins, J. P. Oliveira (1904), O Brasil e as colónias portuguesas. Lisboa: Parceria António Mário Pereira.

Mattoso, José (1998), A identidade nacional. Lisboa: Gradiva.

Mazrui, Ali A.; Tidy, Michael (1984), Nationalism and New States in Africa. London: Heinemann.

Mbembe, Achille (2000), De la postcolonie. Essai sur l'imagination politique dans l'Afrique contemporaine. Paris: Khartala.

McClintock, Anne (1995), Imperial Leather. Race, Gender and Sexuality in the Colonial Conquest. New York: Routledge.

McLeod, John (2000), Beginning Postcolonialism. Manchester/New York: Manchester UP. Memmi, Albert (1965), The Colonizer and the Colonized. New York: The Orion Press.

Mignolo, Water (2000), Local Histories/Global Designs. Coloniality, Subaltern Knowledges, and Border Thinking. Princeton, N.J.: Princeton University Press.

Miranda, A. P. (1954), "Memória sobre a costa de Africa e da Monarquia Africana (c. 1766)," in L. F. C. Dias (org.), Fontes para a história, geografia e comércio de Moçambique (século XVIII). Lisboa: Agência Geral do Ultramar, 47-121.

Monclaro, Padre (1899), "Relaçaõ da Viagem q Fizeraõ os Padres da Companhia de Jesus com Francisco Barreto na conquista de Monomotapa no Anno de 1569," in G. M.Theal (ed.), Records of South-Eastern Africa. Cidade do Cabo: Struik, vol. 3, 157-201.

Mondlane, Eduardo C. (1969), The Struggle for Mozambique. Harmondsworth: Penguin.

Montaigne, Michel de (1965), Complete Essays. Stanford: Stanford UP.

Nandy, Ashis (1999), Traditions, Tyranny and Utopia. Essays in the Politics of Awareness. Delhi: Oxford UP.

Nkrumah, Kwame (1961), I Speak of Freedom. A Statement of African Ideology. London: Heinemann.

Nkrumah, Kwame (1965), Neo-Colonialism. The Last Stage of Imperialism. New York: International Publishers.

Nyerere, Julius K. (1966), Freedom and Unity. Dar es Salaam: Oxford UP.

Owen, W. F. W. (1964), "Letter from Captain W. F. W. Owen to J. W. Crocker, 9 October, 1823," in G. M. Theal (ed.), Records of South-East Africa. Cidade do Cabo: Struik, vol. 9, 32-35.

Pires, Maria Laura Bettencourt (1981), Portugal visto pelos Ingleses. Lisboa: Centro de Estudos Comparados de Línguas e Literaturas Modernas da Universidade Nova de Lisboa. 
Portugal, Joaquim José da Costa (1954), "Notícias das Ilhas de Cabo Delgado," in L. F. C. Dias (ed.), Fontes para a história, geografia e comércio de Moçambique (século XVIII). Lisboa: Agência Geral do Ultramar, 275-310.

Ranger, Terence (1988), "The Invention of Tradition in Colonial Africa," in E. Hobsbawm;

T. Ranger (eds.), The Invention of Tradition. Cambridge: Cambridge UP, 211-262.

Said, Edward (1978), Orientalism. New York: Pantheon Books.

Said, Edward (1980), The Question of Palestine. New York: Vintage.

Sant' Anna, José Firmino (1911), Missão da doença do sonno. Trabalhos de outubro a novembro de 1991 (N'hantsua, Tete). Maputo: Arquivo Histórico de Moçambique, Secção dos Serviços de Saúde (mimeo).

Santos Junior, J. R.; Barros, F. (1950), "Notas etnográficas de Moçambique," in XIII Congresso Luso-Espanhol para o Progresso das Ciências. Lisboa, vol. 5, 609-623.

Santos, Boaventura de Sousa (ed.) (1993), Portugal - Um retrato singular. Porto: Afrontamento.

Santos, Boaventura de Sousa (1994), Pela mão de Alice. O social e o político na pósmodernidade. Porto: Afrontamento.

Santos, Boaventura de Sousa (1995), Toward a New Common Sense. Law, Science and Politics in the Paradigmatic Transition. New York: Routledge.

Santos, Boaventura de Sousa (1999), "On Oppositional Postmodernism," in R. Munck; D. O'Hearn (orgs.), Critical Development Theory, London/New York: Zed Books.

Santos, Boaventura de Sousa (2000), A crítica da razão indolente. Contra o desperdício da experiência. Porto: Afrontamento.

Santos, Boaventura de Sousa (2001) "Os processos da globalização," in B. S. Santos (ed.), Globalização. Fatalidade ou utopia? Porto: Afrontamento.

Santos, Frei João dos (1999), Etiópia Oriental e Vária história de cousas notáveis do Oriente [1609]. Lisboa: Comissão Nacional para as Comemorações dos Descobrimentos Portugueses.

Senghor, Leopold S. (1964), Liberté 1. Négritude et Humanisme. Paris: Seuil.

Senghor, Leopold S. (1977) Anthologie de la nouvelle poesie nègre et malgache de langue francaise (precedée de Orphée noir par Jean-Paul Sartre). Paris: Presses Universitaires de France.

Silva, A. L. (1679), Carta de António Lobo da Silva para o vice rei [da India], escrita no Zimbaboé em 15 de Dezembro de 1679. Lisboa: Arquivo Histórico Ultramarino, Caixa 3 (Documento 77).

Spivak, Gayatri C. (1996), "How to Teach a 'Culturally Different' Book," in Donna Landry; Gerald MacLean (eds.), The Spivak Reader. Selected Works of Gayatri Chakravorty Spivak. New York/London: Routledge, 237-266.

Thiong'o, Ngäugäi wa (1986), Decolonizing the Mind. The Politics of Language in African Literature. London: Heinemann.

Tomkinson, J. (1964), "Report of Captain J. Tomkinson to Vice-Admiral Albermarble Bertie (1809)," in G. M. Theal (ed.), Records of South-East Africa. Cidade do Cabo: Struick, vol. 9, 1-6.

Ulrich, Ruy Ennes (1909), Política colonial, lições feitas ao curso do $4^{\circ}$ ano jurídico no ano de 1908/1909. Coimbra: Imprensa da Universidade.

Vianna, Luiz Werneck (1997), A revolução passiva. Iberismo e Americanismo no Brasil. Rio de Janeiro: Editora Revan, 1997.

Xavier, Ignacio Caetano (1954), "Relação do estado presente de Moçambique, Sena, Sofala, Inhambane e de todo o continente da Africa Oriental," in L. F. C. Dias (ed.), Fontes para a história, geografia e comércio de Moçambique (século XVIII). Lisboa: Agência Geral do Ultramar, 171-217. 